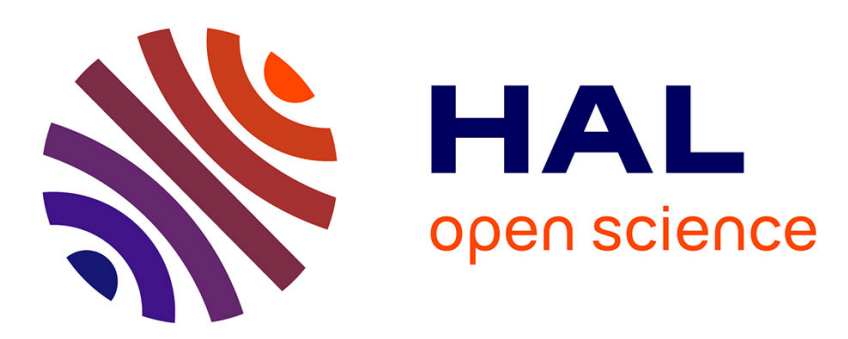

\title{
RE-EMPLOYMENT PROBABILITIES OF UNEMPLOYMENT BENEFIT RECIPIENTS
}

Alfonso Alba, Jose Maria Arranz, Fernando Muñoz-Bullón

\section{To cite this version:}

Alfonso Alba, Jose Maria Arranz, Fernando Muñoz-Bullón. RE-EMPLOYMENT PROBABILITIES OF UNEMPLOYMENT BENEFIT RECIPIENTS. Applied Economics, 2011, pp.1. 10.1080/00036846.2011.579067 . hal-00712375

\section{HAL Id: hal-00712375 https://hal.science/hal-00712375}

Submitted on 27 Jun 2012

HAL is a multi-disciplinary open access archive for the deposit and dissemination of scientific research documents, whether they are published or not. The documents may come from teaching and research institutions in France or abroad, or from public or private research centers.
L'archive ouverte pluridisciplinaire HAL, est destinée au dépôt et à la diffusion de documents scientifiques de niveau recherche, publiés ou non, émanant des établissements d'enseignement et de recherche français ou étrangers, des laboratoires publics ou privés. 


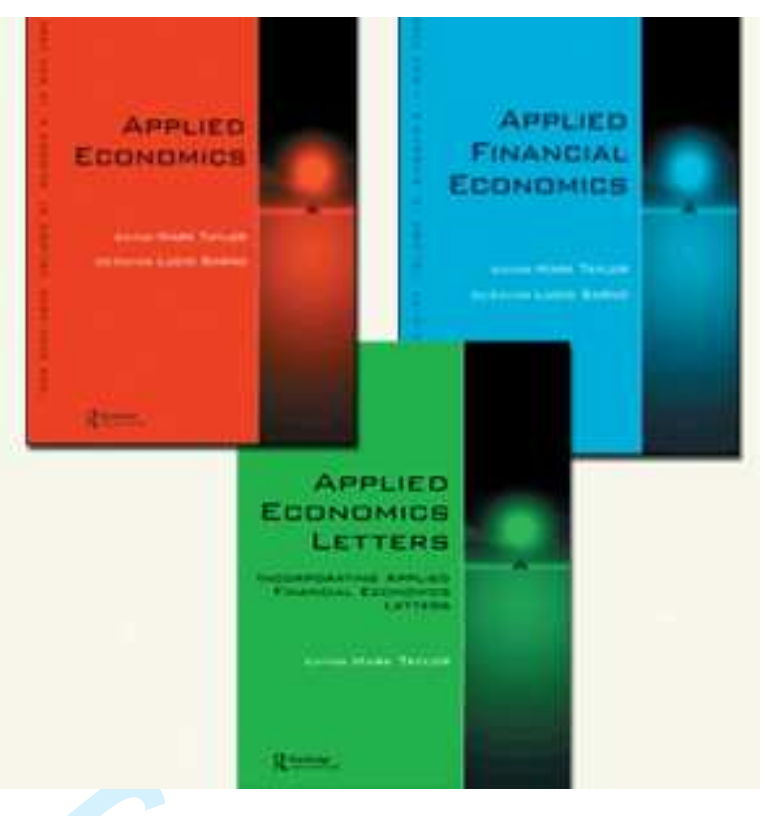

\section{RE-EMPLOYMENT PROBABILITIES OF UNEMPLOYMENT BENEFIT RECIPIENTS}

\begin{tabular}{|c|c|}
\hline Journal: & Applied Economics \\
\hline Manuscript ID: & APE-2009-0710.R1 \\
\hline Journal Selection: & Applied Economics \\
\hline $\begin{array}{r}\text { Date Submitted by the } \\
\text { Author: }\end{array}$ & 24-Mar-2011 \\
\hline Complete List of Authors: & $\begin{array}{l}\text { Alba, Alfonso; Universidad Carlos III de Madrid, Departamento de } \\
\text { Economía } \\
\text { ARRANZ, JOSE; UNIVERSIDAD DE ALCALA, } \\
\text { ESTADISTICA,ESTRUCTURA Y OEI } \\
\text { Muñoz-Bullón, Fernando; Universidad Carlos III de Madrid, Sección } \\
\text { de Organización de Empresas }\end{array}$ \\
\hline JEL Code: & $\begin{array}{l}\text { C41 - Duration Analysis < C4 - Econometric and Statistical } \\
\text { Methods: Special Topics < C - Mathematical and Quantitative } \\
\text { Methods, J64 - Unemployment: Models, Duration, Incidence, and } \\
\text { Job Search < J6 - Mobility, Unemployment, and Vacancies < J - } \\
\text { Labor and Demographic Economics, J65 - Unemployment } \\
\text { Insurance|Severance Pay|Plant Closings < J6 - Mobility, } \\
\text { Unemployment, and Vacancies < J - Labor and Demographic } \\
\text { Economics }\end{array}$ \\
\hline Keywords: & $\begin{array}{l}\text { unemployment duration, recall, unemployment insurance, } \\
\text { unemployment assistance, competing risks model }\end{array}$ \\
\hline
\end{tabular}




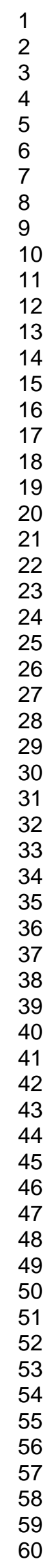

SCHOLARONE ${ }^{\text {M }}$
Manuscripts

10

12

13

14

15

16

18

19

20

22

23

25

26

27

29

32

33

34

35

36

39

40

41

42

44

45

46

47

48

50

51

52

53

54

56

57

58

60

Editorial Office, Dept of Economics, Warwick University, Coventry CV4 7AL, UK 


\section{Re-employment probabilities of unemployment benefit recipients}

This article studies transitions out of unemployment for benefit recipients in Spain. We analyse the duration of unemployment, distinguishing between spells that end in recall (workers returning to the previous employer) and spells that end in exit to a new job. This distinction allows us to find that the recall hazard rate increases around the time of exhaustion of benefits. However, this happens only for workers receiving unemployment insurance. Because we are unable to replicate this result for workers receiving unemployment assistance, we believe the finding lends support to the hypothesis that in Spain firms and workers make a strategic use of unemployment insurance.

Keywords: unemployment duration, recall, unemployment insurance, unemployment assistance, competing risks model.

Codes: C41, J64,J65 


\section{Introduction}

Unemployment spells can end with the worker finding a new job or being recalled by the previous employer. In Spain, more than a third of jobless workers return to the firm where they were previously employed (Alba et al., 2007). ${ }^{1}$ One possible explanation for firms recalling workers after a spell of unemployment is the existence of firm-specific human capital (Pissarides, 1982). Firms have to lay-off workers in periods of sluggish demand and recall some of the workers when their benefits are about to lapse. Running out of benefits makes workers more likely to accept a new job (Juradja, 2003). However, the extent to which a worker's search strategy is mirrored in the firm's recall decisions is an empirical question that motivates a separate estimation of the recall and new job hazards.

In Spain the Unemployment Compensation System (UCS) does not contain any element of 'experience rating' for contributions. This provides an incentive for firms to adjust their labour demand through lay-offs and recalls. In a context of implicit re-employment contracts between workers and firms, the recall hazard rate is expected to rise as the time of unemployment benefit exhaustion approaches. The 'spike' in the re-employment rate at the expiration of unemployment benefits is interpreted as evidence that recipients wait until their benefits run out to return to work-one of the best-known empirical results in public finance and labour economics (see, e.g., Card et al., 2007). ${ }^{2}$

A better understanding of the recall behaviour is important for labour market policy and measures addressing joblessness. Many studies have stressed that

\footnotetext{
${ }^{1}$ Recent work has found recalls to be prevalent in Europe (Fischer and Pichelmann, 1991; Jansson, 2002; Jensen and Svarer, 2003; Mavromaras and Orme, 2004). See, in addition, Robertson (1989) for Canada and Katz and Meyer (1990) for the United States.

${ }^{2}$ See, for instance, Katz and Meyer (1990). For analyses of unemployment duration when benefits are near exhaustion-although the following studies do not distinguish between exits from unemployment through recall or through a new job-see, e.g., Fallick (1991) and Narendranathan and Stewart (1993), who show that the effect of unemployment insurance benefits on the hazard out of unemployment decreases over time, or Micklewright and Nagy (1998), Stancanelli (1999), Bratberg and Vaage (2000) and Puhani (2000), who do not find any rise in the hazard near benefit exhaustion.
} 
individual transitions out of unemployment depend on the extent to which recall by the previous employer is expected (Jensen and Westergård-Nielsen, 1990; Corak, 1996; Rosholm and Svarer, 2001; Jensen and Svarer, 2003; Røed and Nordberg, 2003). In Spain, research on unemployment duration has exclusively focused on the generosity of the UCS without distinguishing recalls from new job hazards (AlbaRamírez, 1999; Bover et al., 2002; Gonzalo, 2002; Jenkins and García-Serrano, 2004; Arranz and Muro, 2007; Arranz et al., 2009).

In this article we study unemployment exit rates around benefit exhaustion. Specifically, we first examine the hypothesis that recalls are synchronized with the expiration of unemployment benefits, using selected data on unemployment benefit recipients in Spain from 2000 to 2002. Employer identifiers in our data set allow us to distinguish unemployment spells ending in new jobs from those ending in recall. Second, prior Spanish literature on unemployment duration has only used information on the duration of insured unemployment - which is a censored estimate of the duration of the jobless spell and, therefore, a poor proxy for the actual time a worker spends without a job (e.g., Arranz and Muro, 2004, 2007; Jenkins and García-Serrano, 2004; Arranz et al., 2009). In this sense, an important departure of our study is that we construct a data set that measures the duration of unemployment, instead of only the length of benefit receipt. We are, therefore, not restricted to analysing exit rates just prior to benefit exhaustion, because we observe the length of the spell during which each worker is actually jobless, instead of only the duration of the unemployment benefits he/she receives-i.e., our data set allows us to know when the unemployed enter employment, either before or after exhausting the unemployment benefits. Therefore, our study also extends the existing Spanish UCS literature in terms of data quality.

Finally, we distinguish between the contributory system-Unemployment Insurance (UI) — and the assistance system-Unemployment Assistance (UA). UA 
constitutes a different benefit scheme aimed at workers whose contribution period falls short of qualifying for UI. This distinction is made mainly for two reasons. First, these two schemes differ as regards their characteristics and objectives. On the one hand, UI is received by unemployed individuals who have worked for a minimum time period (12 months) and its level depends on the worker's previous earnings. On the other hand, unemployed persons who are not entitled to UI might receive UA, so that the main objective of UA is to target the unemployed with a low income in order to reconcile the objective of social equity. UA entitlement depends on whether the individual has family burdens, and the benefit level is based on the statutory minimum wage (see next section). Whereas UI usually allows job seekers to receive offers with more attractive wages (and, therefore, to secure more productive jobs), UA recipients make up a more disadvantaged group in the labour market because they have had less job experience than UI recipients. For this reason, UA recipients are expected to have a weaker attachment to their former employer. By distinguishing between UI and UA and between recall and new job exits from unemployment we make a novel contribution to the literature because previous research on recall duration has not distinguished between the two types of benefits (Røed and Nordberg, 2003; Alba et al., 2007; Fallick and Ryu, 2007³). In addition, the existent studies on UA have exclusively analysed the work disincentive effects arising from the UA scheme, without distinguishing between recall and new job durations. $^{4}$

\footnotetext{
${ }^{3}$ Although Alba et al. (2007) also distinguish between recall and new job exits rates, our analysis differs from theirs in several dimensions. Apart from dividing the sample according to the type of benefits received by the unemployed (either UI or UA), we have information on the level of these two types of benefits and on the individual's unemployment duration beyond the exhaustion point. Therefore, we are able to know when the unemployed enter employment, either before or after exhausting the unemployment benefits.

${ }^{4}$ Studies that analyse the effect of UA on exits from unemployment are scarce. See, for example, Earle and Pauna (1998), Erbenova et al. (1998), Stancanelli (1998), Micklewright and Nagy (1999) or Arranz and Muro (2007).
} 
Our main conclusion is that the UI recall hazard significantly rises at the point of benefit exhaustion. That is, many job seekers are indeed waiting to return to work when their UI elapses. Thus, this article provides the first evidence for Spain on a significant influence of firms' recall policies as determinants of the duration of workers' unemployment benefit spells: the length of time that workers collect benefits is affected by firms' recall decisions. In contrast, the recall hazard rate among UA recipients does not increase around the time of UA exhaustion.

The article is organized as follows. Section II gives a brief description of the Spanish UCS. Section III describes the data and variables. Section IV presents the competing risks duration model. Section V disentangles the estimation results for UI and UA recipients. Finally, conclusions are given in section VI.

\section{The Unemployment Compensation System in Spain}

The Spanish UCS is composed of two parts: UI and UA. On the one hand, individuals who have lost their job involuntarily_including the end of fixed-term contracts-and have worked for 12 months or more during the six years preceding unemployment are eligible for UI benefits. Individuals who have worked for 12-17 months can receive UI for up to 4 months. Those who have worked for 18-23 months can receive up to 6 months, and so on up to a maximum of 24 months of UI for those who have worked for 72 months or longer (see Table 1). The amount of UI is determined as a percentage of the average wage in the 12 months preceding unemployment: $70 \%$ during the first six months of unemployment and $60 \%$ for the remaining period of eligibility. The minimum amount is $75 \%$ of the statutory minimum wage (SMW) if the worker has no dependent children $(100 \%$ if he has dependent children). There is also a maximum equal to $170 \%$ of the SMW, which is raised to $190 \%(220 \%)$ if the unemployed person has one (two or more) dependent child (children). 
There are two key institutional differences between the UI systems in Spain and those in other countries. First, there is the absence of the no experience rating in the Spanish UI tax system. As a result, the unemployment benefit system contains a subsidy element that can lead to an extensive use of recalls. Since UI claimants expecting to be recalled have less of a tendency to search for a new job, ${ }^{5}$ individuals may repeatedly cycle between UI and employment with the same employer. For instance, some individuals might work for the minimum amount of time needed to qualify for benefits (1 year), collect benefits for as long as possible (up to 4 months), be recalled to the previous employer and, finally, repeat the cycle. Thus, instead of searching for a new job, UI recipients may wait for a recall from their previous employer as of the time the benefit is exhausted. At the same time, employers may synchronize their recall decisions according to the unemployment benefit entitlement because laying off a worker with a high potential entitlement is less costly to the firm than laying off an equally productive worker with a low potential entitlement - the former will be less likely to find a new acceptable job with an alternative employer than the latter (Pissarides, 1982).

The second notable characteristic of the UCS in Spain is the availability of $\mathrm{UA}^{6}$ for individuals in the following situations: (1) did not meet the minimum contribution period for eligibility; (2) exhausted UI and has family dependents; (3) returned from foreign migration; (4) was released from prison; (5) an invalidity spell ended by the labour authority declaring the worker able to take a job; (6) aged 52 or

\footnotetext{
${ }^{5}$ It should be stressed that recall is always just a possibility and never a certainty. Unfortunately, we only refer to temporary lay-offs in an ex post sense-i.e., job separations ending in recall. We have no information on ex ante temporary lay-offs-i.e., those that begin with a person expecting to be recalled. In any case, this ex post concept gives the proportion of unemployment from spells involving no job change (Feldstein, 1975; Clark and Summers, 1979), and it is not ambiguous in the sense that it is not based on whether individuals decide on what is a new employer and what is not (see Alba et al., 2007).

${ }^{6}$ As in most European countries; see Van Ours and Vodopivec (2006) for Slovenia; WinterEbmer (1998) or Lalive et al. (2006) for Austria or Fitzenberger and Wilke (2004) for Germany.
} 
older. Of these seven potential situations, we focus on the first one, since our data set only includes UA benefit recipients who do not meet the minimum contribution period for UI eligibility. The level of UA has no relation to previous individual monthly wages. A family income criterion is used whereby per capita family income must not exceed the SMW. A flat rate equal to $75 \%$ of the SMW is paid to all beneficiaries with one or no family dependents, $100 \%$ with two and $125 \%$ with three or more. The receipt of UA is time limited and is conditioned on which of the aboveindicated situations the worker is in (see Table 1).

Thus, due to their larger prior tenure, their ensuing larger firm-specific human capital and their larger levels of unemployment benefit entitlement, UI recipients are expected to have a stronger attachment to their previous employer through recalls. In essence, one may expect the opposite recall outcomes when comparing UI and UA recipients-i.e., firms will prefer to recall UI recipients as they approach the exhaustion of their benefits. ${ }^{7}$ This will cause lower search intensity on the part of UI benefit recipients and lower hiring costs for the firm. The result is increased job attachment while at the same time permitting flexible employment adjustment and reduced risk of losing training investments.

\section{Data, Variable Definitions and Descriptive Analysis \\ The data}

The data have been extracted from the Integrated Benefits System (Histórico del Sistema Integrado de Prestaciones, HSIPRE), a Spanish administrative data set that provides information on the unemployment benefits received by each worker. We use a sample of job losers who entered unemployment under benefits from

\footnotetext{
${ }^{7}$ In any case, one may think that UA recipients in some senses may compete with UI recipients to be recalled. One way to test this possibility would be to include in the estimation for UI (UA) recipients a variable collecting the proportion of UA (UI) recipients that each company recalls in each period of time. However, this variable would be biased because our data set does not collect every unemployed being recalled by each company in the period of analysis.
} 
January to June 2000 - the Spanish UI coverage is rather large (see Blanchard et al., 1995; Toharia, 1997; or Jenkins and García-Serrano, 2004). The quality of this data set is deemed to be high; being administrative in nature, the information is free from the problems common in survey data (such as nonresponse and interviewer bias) (Jenkins and García-Serrano, 2004; Arranz and Muro, 2007; and Arranz et al., 2009). It includes information on the type of benefits received, the claimant's initial entitlement, the current unemployment benefit duration, the number of children the individual has, the monthly benefit amount and the individual's previous earnings.

Unfortunately, the HSIPRE follows recipients only for as long as they collect unemployment benefits. Furthermore, this data set cannot distinguish spells ending in a new job from those ending in a recall. We overcome these deficiencies by merging employment records from the Spanish Social Security (SS) with the HSIPRE. These SS records are reported by every employer (registration with the SS is obligatory for all workers) and include workers' entire employment and unemployment history from June 1999 to June 2002. Since each firm is issued with an (anonymous) identification number-which is separately recorded for every single spell of employment—starting from the unemployment spells under consideration in the year 2000, the recipients' previous and subsequent spells of employment were identified. Thus, we can distinguish recalled workers from those who changed jobs. In addition, the combination of the two data sets allows us to cover not only the period when workers are covered by unemployment benefits but also the period of transition from unemployment to employment when benefits expire. The SS records contain information on the benefit recipients belonging to the HSIPRE data set regarding their age and gender, the qualifications required for the job, the duration of the unemployment spell, the reason for termination of each spell (voluntary/involuntary or retirement), the province of residence of the worker, an identifier of whether 
employment spells are accomplished through a temporary help agency (THA) or not, the type of contract held by the worker (temporary or permanent) and the firm size.

From the initial sample, we drop individuals who do not meet all the following criteria: 1) entered unemployment due to involuntary reasons-i.e., dismissals or termination of temporary contracts. ${ }^{8}$ As we consider only the first spell of unemployment occurring in the indicated period, we obtain a 'flow sample' of unemployed workers in the terminology of Lancaster (1990, p. 162); 2) in the previous job, the individual was registered with the General Social Security Scheme; 3) the individual started receiving UI or UA; 4) workers must remain out of work for more than 30 days. We eliminate workers with unemployment spells lasting 30 days or fewer because they have had movements from job to job without experiencing unemployment. Finally, since the law contemplates early retirement at the age of 52, we limit our sample to workers aged between 16 and 51 years old.

\section{[TABLE 2]}

Deleting observations with missing variables (Table A.1 in the Appendix shows the loss of observations from the initial data set), we are left with a sample of 5,992 individuals (corresponding to 36,282 individual-spell observations), 3,981 of which ended in a new job $(66.43 \%), 1,650$ of which returned to the same employer (27.54\%) and 361 of which were still unemployed at the time of the data extraction or were artificially right censored at 18 months $(6.03 \%) .{ }^{9}$ Therefore, recalls-i.e.,

\footnotetext{
${ }^{8}$ We cannot distinguish between these two reasons for job termination. Nevertheless, we have information on the type of contract held by the individual in his previous job. Workers with permanent contracts are expensive to dismiss, so when they are laid off they are unlikely to come back or to be called back. In addition, a great majority of workers in Spain become unemployed because of the end of their contracts. We understand that the end of a contract is not exactly the same thing as being laid off. By contracting with fixed-term contracts, firms have no need for temporary lay-offs. Workers who quit their jobs (i.e., end their employment for voluntary reasons) are not considered in this study because they can access neither UI nor UA (see section II).

${ }^{9}$ There is a small number of individuals with durations greater than 18 months. In order to avoid noise in the results, we artificially right-censor these observations at 18 months. In addition, although a spell of unemployment can end with an exit from the labour force, the data set does not include an identifier for this possibility. Anyway, observations beyond 18
} 
returning to the same employer-constitute an important element of the unemployment under benefits in Spain.

Table 2 shows the means for selected variables by re-employment outcome and for UI and UA recipients separately. As expected from Section II, these two groups of recipients are markedly different. For instance, the presence of high qualification levels, as well as permanent contracts, is larger among UI recipients, while UA recipients (particularly those who re-enter employment through a new job) have held many more previous jobs on average than UI recipients (and, therefore, have suffered more turnover).

As Table II shows, short unemployment spells usually end in a recall. The average duration of an unemployment spell is shorter for both types of recipients who are recalled than for those who find a new job. Finally, men and younger workers are more likely to change employers.

\section{Variable definitions}

Benefit-related variables. We define a dummy variable that equals 1 for each month that the worker receives UA and zero when UI is received. The impact of unemployment benefits on the hazard is also measured using functions of the time until the benefits lapse. ${ }^{10} \mathrm{We}$ include time until benefit exhaustion dummy variables for seven intervals covering the months before and after the benefits expire. These variables are designated ' $\mathrm{UB}>18$ ' through 'UB $>-10$ '. Each of these time-varying exhaustion dummies takes on the value of one in its designated interval and the value of zero in all other periods. For example, 'UB12-18' takes on the value one when the individual is 12 to 18 months until exhaustion; 'UB0' takes on the value one on the

months are censored, so we regard this inconvenience of the data set as being of minor relevance.

${ }_{10}$ Although the replacement ratio is available, it has not been included because it is problematic to include both the time to benefit exhaustion and the replacement ratio as covariates. The reason is that the replacement ratio drops to zero after the benefits expire (so those variables are probably highly collinear and the estimated effects become imprecise). 
day of benefit exhaustion; 'UB -5 to -10 ' takes on the value one when the individual is 5 to 10 months after benefit exhaustion.

Sociodemographic variables. Apart from gender, we include in the estimation the individual's age at the start of the unemployment spell. The oldest unemployed persons are in possession of skills that are more prone to becoming obsolete, and they are expected to experience more difficulties in adapting themselves to a new job-and, therefore, to stay unemployed for longer (Narendranathan and Nickell, 1985). ${ }^{11}$ Although no information on marital status is available, we do have the individual's number of children (which is a proxy for being married). On the one hand, individuals with children are expected to be more eager to accept any job and those without more able to afford a prolonged job search (the former may also search more intensively for a job, due to their family responsibilities and their subsequent need for more income).

Previous job variables. We consider variables associated with the previous job held by the individual, such as the industry, the type of contract held, the firm size and whether the individual was hired through a temporary help agency or not. In addition, our data set does not contain variables related to the individual's educational attainment or occupation, but the required qualification level in the previous job (a proxy for the educational level). It indicates a position in a ranking determined by the worker's contribution to the Social Security. Therefore, although it is somewhat related to the individual's qualification since it reflects the worker's professional category and salary, it does not reveal the worker's level of

\footnotetext{
${ }^{11}$ The oldest unemployed normally accumulate more labour experience, which generates a higher reservation wage (Folmer and van Dijk, 1988).
} 
qualification, but rather the level of qualification required for the job. ${ }^{12}$ As in previous studies using data from the Social Security records, we group those ten categories into four groups (see Table A.2 in the Appendix). We have no ex ante expectation about the effect of this variable on the hazard out of unemployment: on the one hand, the higher the worker's qualification level, the higher his/her reservation wage and thus the lower the probability of accepting a job offer; on the other hand, employers may prefer those unemployed with higher qualification levels (as they expect greater productivity), so that the probability of exiting from unemployment may be higher.

In addition, we have information on the number of previous jobs held by the individual. ${ }^{13}$ This latter variable collects the number of jobs held prior to the one leading to the spell of unemployment under study, since the database includes the complete employment history of workers from June 1999. It provides us with a measure of the number of times they suffered unemployment from that date. On the one hand, individuals more accustomed to moving jobs may supposedly be more 'employable' (and therefore be expected to leave unemployment earlier), but, on the other hand, such behaviour may signal instability to potential employers (and, thus, they may exit from unemployment later).

We are able to distinguish whether or not the individual entered unemployment from a job with a fixed-term contract, with a permanent contract or with a discontinuous open-ended contract. The latter type of contract allows for interruptions of the labour relation due to seasonality. These interruptions (typically, in autumn and winter) are covered either by working in a different industry or by receiving unemployment benefit receipts. In other words, when each season ends,

\footnotetext{
${ }^{12}$ It may be the case, however, that a worker with higher education is far below the category that would correspond to his formal education. For instance, an individual working in the lowest category, 'labourers', may well be in possession of an academic degree.

${ }_{13}$ Tenure in the previous job is not included in our estimations because of the high correlation between this variable and the benefit entitlement variable (see section II).
} 
workers hired under discontinuous open-ended contracts may be laid off, but they expect an implicit recall by the same firm in the following season. Thus, workers under this latter type of contract enjoy a strong relationship with their previous employer during the lay-off; this relationship is much stronger than with other types of contracts, since individuals retain seniority and other employment-related benefits (for instance, they have the right to return to the same job with the same employer, since they have the privilege of being approached first by their previous employer on their availability to re-enter their payroll). In addition, when being laid off, those individuals receive payments subsidized by the government (through the UI system for the time spent unemployed).

We finally control for the industry in which the worker was engaged in the previous job; some industries may have more fluctuations in demand or supply than others, which means that the tendency to use recalls as a means of smoothing labour force adjustments may be relatively high, other things being equal. Nevertheless, we expect that workers in the service and construction industries will face expanding employment opportunities and higher chances of finding a job. Such industries are characterized by the highest proportions of temporary employment in the Spanish economy. Since worker turnover is high, individuals usually move very frequently from one job (through recalls) to another, and job tenure is usually short.

As regards firm size, its impact is included through five dummy variables: $<=10$ workers, $>10$ and $<=50$ workers, $>50$ and $<=200$ workers, $>200$ and $<=1000$ workers and >1000 workers. Two relevant factors are associated with firm size: the effectiveness of workers' representatives and the cost of lay-offs for the firm. Workers' councils (comités de empresa) can only exist in firms with at least 50 employees (Jimeno and Toharia, 1993). In larger firms, therefore, the relevant legislative constraints that determine the size and effectiveness of the workers' councils are considerably more restrictive with respect to the optimizing behaviour of 
firms (Mavromaras and Rudolph, 1998). Given the costs borne by workers in recalls-in terms of losses in current income, future benefit entitlements, employment security and human capital depreciation during lay-offs-councils are expected to minimize the duration of recalls effectively in larger firms. Moreover, smaller firms can be expected to experience longer recall durations because workers employed by smaller firms will be less able to influence the timing of such recalls. As the firm size increases, there will be more and stronger workers' councils with both the power and the incentive to intervene and assist workers' optimizing behaviour.

Other variables. Regional labour market and household conditions are also taken into account, through dummies for the 17 Spanish Autonomous Communities and the quarterly regional unemployment rate as a time-varying covariate. We expect that the unemployed who live in regions with low regional unemployment rates will enjoy a higher probability of finding a job since there will be less competition for existing vacancies.

Finally, seasonal effects are captured by a set of dummy variables indicating whether workers entered into unemployment in January-February, March-April or May-June. Finally, a duration dependence pattern through a number of monthly dummies used for the baseline hazard specification is included for each exit rate.

\section{Nonparametric analysis}

Empirical job finding rates_-distinguishing between a new job and a recall— are shown in Figs. 1A and 1B for UI and UA recipients, respectively (the standard errors were used to construct confidence bands in the figures). The estimate in a given month is the proportion of the number of unemployed who make a particular type of transition to the number of those individuals who are still unemployed in that 
month. In constructing these figures, we make the conventional assumption of independent competing risks (e.g., Katz and Meyer, 1990); the hazard plot for recalls treats job starts as censored, while the hazard plot for new job starts treats recalls as censored. As Fig. 1A shows, the new job finding hazard overall slightly decreases among UI recipients (except for some spikes that might reflect imminent exhaustion of entitlement) up to the 11 months of unemployment; from this month onwards, the new job hazard rate increases throughout the course of the spell. On the other hand, the recall hazard rate also has a declining behavior up to the eleventh month, shows a notable spike around the first year of unemployment, and finally declines just after the thirteenth month, remaining close to a flatter line from the fourteenth month onwards. Among UA recipients (Fig. 1B), the new job hazard increases at an accelerating rate from the thirteenth month onwards, and it remains above the recall hazard, except for during the eighth month of unemployment.

\section{[FIGURE 1A \& 1B]}

We now study the effect of the potential duration on the exit rates from unemployment. Fig. 2A plots the proportion of UI recipients who find a new job and who are recalled to their previous job. Fig. $2 \mathrm{~B}$ shows the corresponding series for individuals eligible for UA. A positive integer in the $\mathrm{x}$-axis indicates that some months remain before benefit exhaustion, while a negative integer indicates that some months have passed since benefit exhaustion. Among UI recipients (Fig. 2A), the new job exit rate is always above the recall exit rate. Moreover, the recall exit rate gradually increases when five months remain to exhaustion and up to the month of benefit exhaustion (corresponding to time 0). On the contrary, the new job exit rate only increases up to the moment when three months remain to benefit expiration. From then on, the likelihood of both finding a new job and being recalled diminish. On the contrary, among UA recipients (Fig. 2B), both the new job and the recall exit rates are at relatively low levels in the months immediately preceding exhaustion. In 
addition, there are no apparent spikes around benefit exhaustion either among individuals who are recalled or among individuals who find a new job.

In essence, the increasing recall rate at exhaustion among UI recipients (Fig. 2A) suggests that recalls serve as persuasive evidence of the strategic use of compensated unemployment by both workers and firms. The rise in the recall rate begins some months before exhaustion and vanishes after the final month of the claimant's entitlement. Thus, recalls are likely to be retimed in order to coincide with the expiration of benefits (compared with the finding of new jobs), and after UI benefit exhaustion, the longer a worker remains unemployed, the lower is the recall (and new job finding) probability. Thus, if the UI recipient is not recalled at benefit expiration, she will be substantially less likely to be recalled thereafter, consistent with the hypothesis of Katz (1986). On the contrary, UA recipients mainly re-enter employment (either through recall or through finding a new job) once some months have passed since benefit expiration. Thus, the strategic use of the unemployment benefit is not so apparent among UA recipients.

[FIGURE 2A \& 2B]

\section{A Competing Risks Duration Model}

We specify a discrete-time duration model with competing risks of exits following the formulation proposed by Allison (1982) and used and extended by Steiner (2001), Lauer (2003) and D’Addio and Rosholm (2005), among others. This type of model is common in the analysis of temporary lay-offs where all the unemployed are subject to the competing risks of a recall and a new job (Katz, 1986; Røed and Nordberg, 2003; Alba et al., 2007). To model the transition from unemployment to employment through recall or a different employer, we define the discrete hazard rate with competing risks for each different kind of event as (see Allison, 1982): 


$$
\mathrm{h}_{\mathrm{ij}}(\mathrm{t})=\operatorname{Pr}\left[T_{i}=t_{i}, J=j \mid T_{i}>=t_{i}\right]
$$

where $t_{i}$ is the length of individual i's unemployment spell; $i=1 \ldots n$ are individuals. The unemployment spell can end, $T=t$, in any of $j$ states: $j=1$ (re-employment through a new job) or $j=2$ (re-employment through the same employer as the immediately previous one; that is, a recall takes place). Each observation continues until time $\mathrm{t}_{\mathrm{i}}$, at which point an event occurs or the observation is censored. Unemployment spells that are still in progress at the end of our sampling frame (that is, no transition out of unemployment has been observed until duration T) are treated as right-censored observations. For these observations, both destination indicators are 0 . It is assumed that the time of censoring is independent of the hazard rate for the occurrence of events, at least after controlling for other factors. It is also assumed that the set of two states at which unemployment spells end is absorbing and equal for each person.

Assuming that the competing risks are independent, the hazard rate from unemployment is given by:

$$
h_{i}(t)=\sum_{j=1}^{2} h_{i j}(t)
$$

Assuming that all spell observations are independent, the likelihood function for the original state $j$ can be written in terms of hazard rates as follows (Allison, 1982, p. 88):

$$
L=\prod_{i=1}^{n}\left[\prod_{j=1}^{2}\left[\frac{h_{i j}(t)}{\left(1-h_{i j}(t)\right.}\right]^{\delta_{i j}}\left[\prod_{k=1}^{t}\left(1-h_{i k}\right)\right]\right]
$$

In this expression, we suppose that individual $i$ experiences event $\mathrm{j}$ at time $\mathrm{t}_{\mathrm{i}}$ or else is censored at $\mathrm{t}_{\mathrm{i}}$. As usual, the indicator function $\delta_{i}$ equals one if an event occurred at time $t_{i}$ (complete duration) or else is censored at $t_{i}$. Therefore, the first component of [3] captures the transition rate and the second component is the survivor function. 
Given that [3] is a function of the transition rates, we just need to specify the dependence of the latter on a set of explanatory variables. For the hazard rate we choose the logistic specification that, with multiple events, generates the multinomial logit model (Maddala, 1983). It allows for the three possible states considered: employment through a different employer; employment through recall; and remaining unemployed (which is the reference state category). For individual $i$, the transition rate to state $j$ in period $t$ specified as a multinomial logit can be written as (Steiner, 2001; D’Addio and Rosholm, 2005):

$$
h_{j}\left(\mathrm{t} \mid \mathrm{z}(t), \varepsilon_{j}\right)=\frac{\exp \left(D^{\prime}(t) \alpha_{j}+Z^{\prime}(t) \beta_{j}^{\prime}+\varepsilon_{j}\right)}{1+\sum_{m=1}^{2} \exp \left(D^{\prime}(t) \alpha_{m}+Z^{\prime}(t) \beta_{m}+\varepsilon_{m}\right)}
$$

where $\mathrm{Z}(t)$ is a vector of explanatory variables that may vary with time; $\beta$ is the vector of parameters to be estimated; $\alpha$ stands for the baseline hazard that captures the duration dependence. For the specification of the baseline hazard, we choose a piecewise constant hazard approach by specifying monthly dummies $D(t)$, of which the coefficients for transitions to employment through recall can differ from those for transitions to employment through a different employer. Finally, in our analysis $\varepsilon$ accounts for unobserved heterogeneity characteristics in the model such as motivation, ability, effort, etc. We assume that $\varepsilon$ is destination state specific, time constant and independent of the observed characteristics.

The contribution to the likelihood function for a single individual is equal to (D'Addio and Rosholm, 2005):

$$
L(\beta, \alpha \mid \varepsilon)=\prod_{k=1}^{t} \frac{\exp \left[\left(D_{k}^{\prime} \alpha_{1}+Z_{k}^{\prime} \beta_{1}+\varepsilon_{1}\right) \mathrm{q}_{1 k}+\left(D_{k}^{\prime} \alpha_{2}+Z_{k}^{\prime} \beta_{2}+\varepsilon_{2}\right) q_{2 k}\right]}{1+\sum_{m=1}^{2} \exp \left(D_{k}^{\prime} \alpha_{m}+Z_{k}^{\prime} \beta_{m}+\varepsilon_{m}\right)}
$$

where $\mathrm{q}_{\mathrm{jk}}$ are indicators for making the transition to each of the possible destination states at time k: re-employment through a different employer from the immediately previous one $(j=1)$ or though the same employer $(j=2)$. Unemployment spells in 
progress at the end of the observation period are right-censored observations and for these observations, both destination indicators are 0 . In [5] we assume that unobserved heterogeneity is discretely distributed with unknown support points (see Heckman and Singer, 1984 for the advantages of this distribution). Then, the likelihood function for an individual may be obtained by integrating the following conditional likelihood distribution:

$$
L(\beta, \alpha, \varepsilon, \pi)=\prod_{s=1}^{S} L(\beta, \alpha \mid \varepsilon=s) \pi(s)
$$

where $\varepsilon$ are the location points (that can be interpreted as intercepts for the baseline hazard function), $\pi$ the probability associated with them and $s$ the number of support points. In the following section we estimate this likelihood function by maximum likelihood to discover how individual and labour market characteristics influence unemployment spell durations via recall or a new job. ${ }^{14}$

\section{Estimation Results}

According to the estimation results for the entire sample (see Table A.3 in the Appendix), UA recipients re-enter employment later via recall and through finding a new job than UI recipients. In particular, UA recipients are $25 \%$ less likely to reenter employment via recall than UI recipients. Thus, UI recipients enjoy greater attachment to their former employers, since they expect to be recalled sooner than UA recipients. This finding is consistent with the existence of implicit contracts

\footnotetext{
${ }^{14}$ We perform a test (available from the authors upon request) for the assumption of 'independence of irrelevant alternatives' (IIA) through the Hausman test (Hausman and McFadden, 1984, HM) and Small-Hsiao test (Small and Hsiao, 1985, SH). In both tests, the null hypothesis of IIA is not rejected; therefore, the multinomial logit specification shows no indication that it is inappropriate for each arrival state (new job or recall). In addition, a Wald test and an LR test are performed (also available from the authors upon request) in order to examine the null hypothesis that the coefficients of each category do not differ significantly from each other, for all the possible combinations. The rejection of the null hypothesis means that it is adequate to distinguish between exits into a new job and exits into a recall job; therefore, the competing risk specification seems to be appropriate, since none of the categories should be combined.
} 
between firms and UI recipients: firms prefer to rehire first individuals whom they already know and value (which is typical of UI recipients). Thus, it is important, as already pointed out in Section II and the Introduction, to analyse the re-employment behaviour of UI and UA recipients separately. For this purpose, Table 3 presents the estimation results for these two groups of unemployed individuals separately.

\section{[TABLE 3]}

The estimations are obtained based on the likelihood function (6) by the maximum likelihood estimator. ${ }^{15}$ Given that both support points are highly significant in any specification of the model, exit rates into recall or new jobs are affected not only by the measured individual and job characteristics of the unemployed, but also by the unobserved characteristics of the unemployed. Estimated coefficients and the value of the log-likelihood are affected by the inclusion of unobserved heterogeneity. In particular, unobserved heterogeneity increases the log-likelihood values in the estimations, which indicates an improvement in the fit of the model. ${ }^{16}$

Interesting insights arise from the time until exhaustion variable. In particular, the effect of entitlement benefit duration on the hazard rate out of unemployment is different according to the route taken back to work. UI recipients exit through recall faster as the moment of benefit exhaustion approaches. The recall hazard rate for these individuals has a large spike at the point of benefit exhaustion (it is more than three times larger than in the reference period). Moreover, it remains large in the four months after benefit exhaustion. Thus, among those UI recipients who are recalled, this outcome is expected to be more likely to occur either at the moment of benefit

\footnotetext{
${ }^{15}$ We use an identification theorem of Han and Hausman (1990), which gives conditions under which the competing risk model is identified even if the covariates for each risk are identical. The identification condition basically requires the presence of at least two continuous variables among the covariates. Our estimation includes several continuous variables: age, age squared and the regional unemployment rate.

${ }^{16}$ A simple likelihood ratio test of a model with unobserved heterogeneity against another without unobserved heterogeneity confirms the conclusion that unobserved heterogeneity is significant (these tests are available from the authors upon request).
} 
exhaustion or once their benefits have run out to return to work. In contrast, although the hazard rate into a new job for these individuals also rises as the moment of exhaustion approaches, it is less than twice as much as the reference period on the day of exhaustion. This behaviour reflects the joint effect of a falling reservation wage and rising job search intensity as the UI is close to exhaustion (Mortensen, 1977). Similar evidence has been found in other empirical studies. For instance, Card et al. (2007) also found for Austria a large spike in the exit rate at the point of benefit exhaustion (for both new jobs and recalls), and that the hazard rose only slightly thereafter.

In contrast, the recall hazard rate for UA recipients is lower as benefit exhaustion approaches, at the moment of benefit exhaustion and thereafter (relative to the reference period). Therefore, not only are UA recipients less likely to exit from unemployment via recall than UI recipients (as previously commented on), but also their recall is not being timed according to the impending exhaustion of UA benefits. In addition, the new job hazard rate for UA recipients is not significantly different depending on the remaining period to exhaustion. This result underscores the importance of distinguishing between the effects of UI and UA programmes on the decision of recipients to exit from unemployment to a recall or a new job.

In addition, most of the sociodemographic variables have different effects on the two hazard rates. The time profiles of the recall and new job hazard rates differ by gender, age, the qualification required by the job and the number of children. Men have a larger cause-specific hazard for exiting from unemployment through a new job (under both types of benefits). However, males who receive UI are less likely to be re-employed by their previous employer than women. Age is an important determinant of recall hazards among UI recipients. As age rises, the lower the recall hazard rate is, up to a minimum of 25 years old (from then on, the hazard rises). This negative impact on the recall hazard rate for the youngest unemployed is most 
probably caused by demand-side effects; employers do not desire to rehire persons with insufficient firm-specific human capital (given the high cost of acquisition in the open market). In addition, it is possible that young workers are deliberately searching for new jobs that match their preferences more accurately (which may very well vary for young persons). Moreover, the UI recipients with the highest qualification levels are more likely to exit from unemployment through recall, while the qualification level presents a nonsignificant impact on the recall hazard rate for UA recipients. Finally, the number of children is another significant variable: individuals without children exit sooner to a new job than the remaining ones, which may suggest that they are more willing to accept job offers (in essence, they are more mobile). In contrast, evidence exists of a null effect of the number of children on the recall hazard rate.

As regards the variables collecting the characteristics of the job previously held, firm size plays an important role. As stated in section III above, for both groups of benefit recipients, the larger the firm size is, the higher the recall hazard rate is. A likely interpretation is that individuals employed by smaller firms will be less able to influence the timing of their recall outcome, whereas workers' councils in larger firms will be able to favour workers' optimizing behaviour. In addition, the individuals' new job hazard rate is also larger in relatively large firms among UI recipients, but not among UA recipients. Concerning the industry of employment, UI recipients in services suffer a lower transition rate from unemployment into a recall job than those in manufacturing. This result is expected in as much as workers previously employed in manufacturing (and particularly in larger firms) move from one job to another with relatively high frequency. We also appreciate that workers receiving UI and who have worked in the services industry are more likely to find a new job. 
The duration of recall spells is shorter for benefit recipients who have held either temporary contracts (among UI recipients) or discontinuous open-ended contracts in their previous job (among both UI and UA recipients). This is reasonable, to the extent that workers under discontinuous temporary contracts enjoy a stronger relationship with their previous employer while they are unemployed. Thus, they do not usually engage in job-seeking activities because they regard themselves as employed and may be virtually certain to return to their jobs at the end of the lay-off period. As a result, benefit entitlement creates incentives for employers to offer fixed-term rather than permanent contracts.

Finally, as regards the state of labour market demand, the unemployed who receive UI and live in regions with a lower regional unemployment rate enjoy a higher probability of finding a recall job, since there may be less competition for existing vacancies in their respective locations.

\section{[FIGURE 3A]}

As regards duration dependence, Fig. 3A shows the predicted hazard rate at the means of covariates for UI recipients, while Fig. 3B does so for UA recipients (after controlling for observed and unobserved heterogeneity). As we will see, the fact that the hazard rates for these two groups of benefit recipients show different duration dependence patterns illustrates the danger of estimating a single risk hazard rate, instead of a competing risks model. Among UI recipients the estimated hazard for finding a new job lies above the estimated recall hazard rates. This result is sensible to the extent that recalls may carry a higher wage due to the accumulation of firm-specific human capital—see, e.g., Fallick and Ryu (1997). The new job hazard rate shows no clear duration dependence up to the eleventh month; from then on, positive duration dependence is apparent. Presumably, increased search activity as unemployment duration lengthens results in increases in the new job hazard rate. In contrast, the recall hazard rate firstly rises up to the second month and then shows a 
decreasing pattern. ${ }^{17}$ A likely interpretation of the fact that the likelihood of being recalled is more likely during the first months in unemployment is that firms' risk of losing employees on temporary lay-off increases with unemployment duration; as a result, this makes recall by the employer earlier. These results are, therefore, coherent with those found by Katz (1986), Katz and Meyer (1990), Corak (1996) and Jensen and Nielsen (1999).

\section{[FIGURE 3B]}

Among UA benefit recipients (Fig. 3B), the hazard of finding a new job is above the recall hazard rate. Given that the majority of UA recipients in our sample are entitled to 6 months of unemployment benefits, we observe that there is an increase in the fourth month of unemployment in the UA recall hazard rate but we appreciate no increases in the recall hazard rate either at the moment of benefit exhaustion or one month before or after benefit exhaustion. Therefore, we conclude that there is no duration dependence in the recall hazard rate among UA benefit recipients. Finally, among UI benefit recipients, a spike in the fifth month of unemployment for transitions into a new job is observed.

\section{Conclusions}

In this article, we have examined the re-employment probabilities of unemployment benefit recipients in Spain. Our focus has been on how the unemployment benefit compensation system affects the exit from unemployment via either recall or the finding of a new job. For this purpose, we have distinguished between the unemployed receiving UI and those receiving UA, since UI benefits are typically received by workers with longer previous jobs (while UA benefits are

\footnotetext{
${ }^{17}$ Similar results are also detected by Katz (1986) and by Fallick and Ryu (2007), who in their analysis of unemployed persons with and without UI benefits find that the new job hazard rate more or less increases over the course of the unemployment spell and the estimated recall hazard rate exhibits negative duration dependence.
} 
typically received by workers who do not meet the minimum contribution period for UI eligibility). The data set used contains information on the characteristics of workers who became unemployed from January to June 2000, their work history, unemployment duration and benefit-related variables.

Apart from the fact that individual characteristics influence the recall and new job hazard rates differently, UI recipients leave unemployment sooner than UA recipients (as expected). However, the former are more likely to be recalled as the exhaustion of UI approaches, at the point of benefit exhaustion and after some months have passed since benefit exhaustion. In contrast, the recall hazard rate among UA recipients decreases as UA exhaustion approaches.

The indicated results suggest that the duration of unemployment benefits has a strong influence on firm recall policies and workers' new job finding behaviour, which confirms the importance of distinguishing between UI and UA benefit recipients when analysing the transition from joblessness to employment. In particular, the fact that the chances of being recalled among UI recipients increase markedly around the time of benefit exhaustion can be interpreted from both the demand and the supply side of the market: as the exhaustion of benefits approaches, firms appear to time their recall decisions to coincide with the benefit entitlement of their recalled workers. In addition, no pattern is discernible among UA recipients, whose exit rates increase after the benefit exhaustion period. The fact that the exit of UA recipients from unemployment is mainly observed after the exhaustion of benefits suggests a context in which firms are more interested in recalling UI benefit recipients mainly because of their higher job attachment. Therefore, firms recall UA benefit recipients only after UI recipients have already been recalled or re-employed elsewhere.

These results imply that it can be a joint decision of both workers and their employers that determines how the unemployment compensation system is used. In 
particular, the finding that firms do not recall workers until they are about to exhaust their unemployment insurance benefits suggests that, when the need for a temporary employment adjustment arises, employers may rely more on temporary lay-offs and less on other adjustment mechanisms because they can shift part of the cost of the adjustment to the public purse through unemployment insurance. From a policy point of view, the risk that UI benefits may artificially subsidize the regular use of recalls by employers suggests a limit to benefit payments to temporarily laid-off employees through administrative rules. In this regard, the benefit administration would need to assess the frequency of UI claims associated with recalls that seem to have no real insurance function, and the effectiveness of particular measures to limit them (see e.g., Jurajda, 2004). 


\section{REFERENCES}

Allison, P.A. (1982) Discrete-time methods for the analysis of event histories, in Leinhardt, S. (ed.), Sociological Methodology. San Francisco: Jossey-Bass Publishers, pp. 6198.

Alba-Ramírez, A. (1999) Explaining the transitions out of unemployment in Spain: the effect of unemployment insurance, Applied Economics, 31, 183-193.

Alba-Ramírez, A., Arranz, J. M. and Muñoz-Bullón, F. (2007) Exits from unemployment: recall or new job, Labour Economics, 14, 788-810.

Arranz, J. and Muro, J. (2004) Recurrent unemployment, welfare benefits and heterogeneity, International Review of Applied Economics, 18 (4), 423-441.

Arranz, J.M. and Muro, J. (2007) Duration data models, unemployment benefits and bias, Applied Economics Letters, 14(5), 1119-1122.

Arranz, J.M., Muñoz-Bullón F. and Muro, J. (2009) Do unemployment benefit legislative changes affect job finding?, Moneda y Crédito, 228, 7-44.

Bover, O., Arellano, M. and Bentolila, S. (2002) Unemployment duration, benefit duration, and the business cycle, Economic Journal, 112, 1-43.

Blanchard, O., Jimeno, J.F., Andrés, J., Bean, C., Malinvaud, E., Revenga, A., Saint-Paul, G., Snower, D.J., Solow, R., Taguas, D. and Toharia, L. (1995) Spanish unemployment: Is there a solution?, Centre for Economic Policy Research, London.

Bratberg, E. and Vaage, K. (2000) Spells durations with long unemployment insurance periods, Labour Economics, 7, 153-180.

Card, D., Chetty, R., and Weber, A. (2007) The spike at benefit exhaustion: leaving the unemployment system or starting a new job? American Economic Review Papers and Proceedings ,97, 113-118.

Clark, K.B. and Summers, L.H. (1979) Labor market dynamics and unemployment: A reconsideration. Brookings Papers Economics on Economic Activity, 1, 13-60.

Corak, M. (1996) Unemployment insurance, temporary layoffs and recall expectations, Canadian Economic Observer, Statistics Canada, no. 11, May, 3.1-3.15. 
D' Addio, A.C. and Rosholm, M. (2005) Exits from temporary jobs in Europe: a competing risks analysis, Labour Economics, 12, 449-468.

Earle, J.S. and Pauna, C. (1998) Long-term unemployment, social assistance and labour market policies in Romania, Empirical Economics, 23, 203-235.

Erbenova, M., Sorm, V. and Terrel, K. (1998) Work incentive and other effects of social assistance and unemployment benefit policy in the Czech Republic, Empirical Economics, 23, 87-120.

Fallick, B.C. (1991) Unemployment insurance and the rate of re-employment of displaced workers, Review of Economics and Statistics, 73, 228-235.

Fallick, B.F. and Ryu, K. (1997) Structural duration analysis of lay-off unemployment spell: recall vs. new job. Draft.

Fallick, B. and Ryu, K. (2007) The recall and new job search of laid-off workers: a bivariate proportional hazard model with unobserved heterogeneity, The Review of Economics and Statistics, May, 89(2), 313-323.

Feldstein, M. S. (1975) The importance of temporary layoffs: an empirical analysis, Brookings Papers on Economic Activity, 3, 725-744.

Fischer, G. and Pichelmann, K. (1991) Temporary layoff unemployment in Austria: empirical evidence from administrative data, Applied Economics, 23, 1447-1452.

Fitzenberger, B. and Wilke, R.A. (2004) Unemployment durations in West-Germany before and after the reform of the Unemployment Compensation System during the 1980s, ZEW, Discussion Paper No. 04-24.

Folmer, H. and Van Dijk, J. (1998) Differences in unemployment duration: a regional or a personal problem?, Applied Economics, 20, 1233-1251.

Gonzalo, M.T. (2002) A new look at the UI effect on transitions from unemployment into wage employment in Spain: the limited duration of the UI benefits entitlement, Applied Economics, 34, 2177-2187.

Han, A. and Hausman, J.A. (1990) Flexible parametric estimation of duration and competing risk models, Journal of Applied Econometrics, 5(1), 1-28.

Hausman, J.A. and McFadden, D. (1984) Specification tests for the multinomial logit model, Econometrica, 52 (2), 1219-1240. 
Heckman, J.J. and Singer, B. (1984) A method for minimising the impact of distributional assumptions in econometric models for duration data, Econometrica, 52, 272-320.

Jansson, F. (2002) Rehires and unemployment duration in the Swedish labour market - new evidence of temporary layoffs. Labour, 16 (2),311-345.

Jenkins, S.P. and García-Serrano, C. (2004) The relationship between unemployment benefits and re-employment probabilities: evidence from Spain, Oxford Bulletin of Economics and Statistics, 66(2), 239-260.

Jensen, P. and Nielsen, M.S. (1999) Short- and long-term unemployment: how do temporary layoffs affect this distinction?, Working Paper 99-06, Centre for Labour Market and Social Research, Aarhus.

Jensen P. and Westergärd-Nielsen N. (1990) Temporary layoffs, in J. Hartog (ed.), Panel Data and Labor Market Studies, North-Holland, Amsterdam.

Jensen, P. and Svarer, M. (2003) Short- and long-term unemployment: how do temporary layoffs affect this distinction?, Empirical Economics, 28(1), 23-44.

Jimeno, J.F. and Toharia, L. (1993) Spanish labour markets: institutions and outcomes, in J. Hartog and J. Theeuwes (eds.), Labour Market Contracts and Institutions, Elsevier Science Publishers, pp. 299-322.

Juradja, S. (2003) Unemployment insurance and the timing of layoffs and recalls, Labour, 17 (3), 383-389.

Jurajda, S. (2004) Recalls and unemployment insurance taxes, Applied Economics Letters, 11, 651-656.

Katz, L.F. (1986). "Layoffs, recall and the duration of unemployment", NBER Working Paper no. 1825, January.

Katz, L. F. and Meyer, B.D. (1990) The impact of the potential duration of unemployment benefits on the duration of unemployment, Journal of Public Economics, 41, 45-72.

Lauer, C. (2003) Education and unemployment: a French-German comparison, Discussion Paper 03-34, ZEW. 
Lalive, R., J. C. Van Ours, and Zweimüller, J. (2006) How changes in financial incentives affect the duration of unemployment, Review of Economic Studies, 73 (4), 10091038.

Maddala, G.S. (1983) Limited Dependent and Qualitative Variables in Econometrics, Cambridge University Press, Cambridge.

Mavromaras, K. G. and Rudolph, H. (1998) Temporary separations and firm size in the German labour market, Oxford Bulletin of Economics and Statistics, 60 (2), 215-226.

Mavromaras, K.G. and Orme, C.D. (2004) Temporary layoffs and split population models, Journal of Applied Econometrics, 19, 49-67.

Micklewright, J. and Nagy, G. (1998) Unemployment assistance in Hungary, Empirical Economics, 23, 155-175.

Micklewright, J. and Nagy, G. (1999) Living standards and incentives in transition: the implications of UI exhaustion in Hungary, Journal of Public Economics, 73, 97-319.

Mortensen, D.T. (1977) Unemployment insurance and job search decisions, Industrial and Labor Relations Review, 30, 505-517.

Narendranathan, W. and Nickell, S. (1985) Modelling the process of job search, Journal of Econometrics, 28, 29-49.

Narendranathan, W. and Stewart, M. (1993) How does the benefit effect vary as unemployment spells lengthen?, Journal of Applied Econometrics, 8, 361-381.

Pissarides, C. A. (1982) Job search and the duration of layoff unemployment. Quarterly Journal of Economics, 97 (4), 595-612.

Puhani, P.A. (2000) Poland on the dole: the effect of reducing the unemployment benefit entitlement period during transition, Journal of Population Economics, 13, 35-44.

Robertson, M. (1989) Temporary layoffs and unemployment in Canada, Industrial Relations, 28, 83-90.

Røed, K. and Nordberg, M. (2003) Temporary layoffs and the duration of unemployment, Labour Economics, 10, 381-398.

Rosholm, M. and Svarer, M. (2001) Structurally dependent competing risks, Economics letters, 73, 169-173. 
Small, K.A. and Hsiao, C. (1985) Multinomial Logit Specification Tests, International Economic Review, 26 (3), 619-627.

Stancanelli, E. (1998) Unemployment compensation schemes and unemployment duration, Applied Economics Letters, 5, 675-680.

Stancanelli, E. (1999) Unemployment duration and the duration of entitlement to unemployment benefits: an empirical study for Britain, Applied Economics, 31, 1043-1051.

Steiner, V. (2001) Unemployment persistence in the West German labor market: negative duration dependence or sorting ?, Oxford Bulletin of Economics and Statistics, 63, 91-113.

Toharia, L. (1997) Spain, labour market studies Series No. 1, employment and social affairs, European Commission, Brusells.

Van Ours, C. Jan and Vodopivec, M. (2006) How shortening the potential duration of unemployment affects the duration of unemployment: evidence from a natural experiment, Journal of Labor Economics, 24(2),351-378.

Winter-Ebmer, R. (1998) Potential unemployment benefit duration and spell length: lessons from a quasi-experiment in Austria, Oxford Bulletin of Economics and Statistics, 60 (1), 33-45. 


\section{APPENDIX}

Table A.1 Sample selection

\begin{tabular}{lr}
\hline Number of individuals in the initial sample & $\mathbf{7 9 , 2 6 5}$ \\
\hline Observations deleted due to: & 21,702 \\
- Non involuntary separation from the job & 50,164 \\
- Do not take up unemployment benefits & 460 \\
- Aged 52 o more year & \\
- Missing variables & 1 \\
- Sex & 1 \\
$-\quad$ Industry & 5 \\
- Entitlement period & 16 \\
- Unemployment benefit different from insurance or assistance & 920 \\
Number of individuals in the sample used for the empirical analysis & $\mathbf{5 , 9 9 2}$ \\
\hline
\end{tabular}

Table A.2 Occupation category groups

\begin{tabular}{|c|c|}
\hline $\begin{array}{l}\text { Qualification level } \\
\text { according } \\
\text { to Social Security } \\
\text { classification } \\
\text { of jobs }\end{array}$ & Social Security classification of jobs \\
\hline High & $\begin{array}{l}\text { 1. Workers with university degree } \\
\text { 2. Technical engineers, experts and qualified assistants } \\
\text { 3. Administrative chiefs and of workshop }\end{array}$ \\
\hline Upper-Intermediate & $\begin{array}{l}\text { 4. Non-qualified assistants } \\
\text { 5. Administrative officials } \\
\text { 6. Secondary (Minor) }\end{array}$ \\
\hline Lower-Intermediate & $\begin{array}{l}\text { 7. Administrative assistants } \\
\text { 8. Officials of the first and the second }\end{array}$ \\
\hline Low & $\begin{array}{l}\text { 9. Officials of third and specialists } \\
\text { 10 Labourers }\end{array}$ \\
\hline
\end{tabular}


Table A.3 Discrete time duration model estimates by type of exit for the entire sample

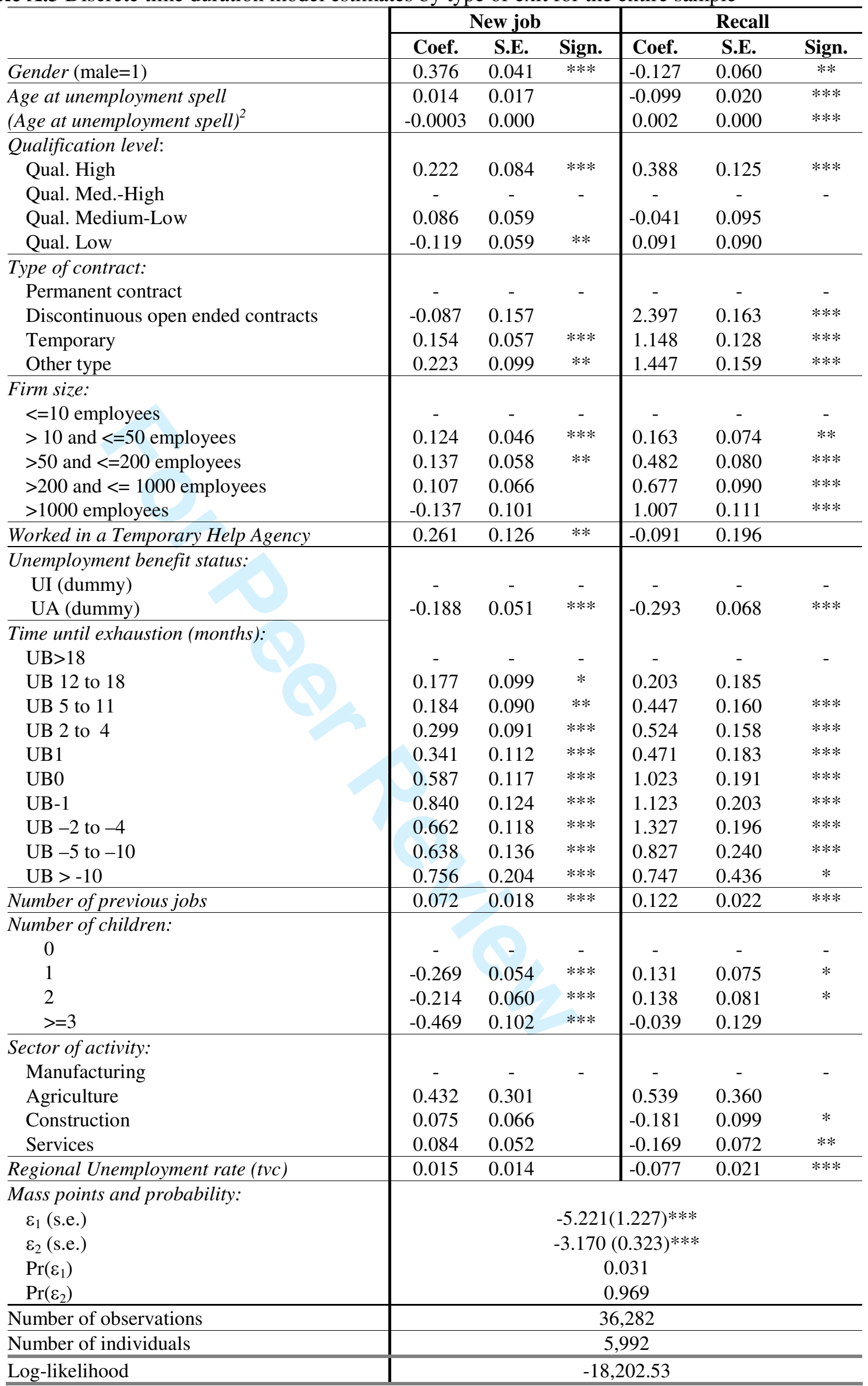

Note: Regression includes controls for 17 regions, unemployment duration (in months) dummies variables (baseline), month of entering unemployment. "tvc" means time varying covariate. *** Indicates significance at $1 \%$; ** indicates significance at $5 \%$; indicates significance at $10 \%$. 
Table 1. The unemployment compensation system in Spain

\begin{tabular}{|c|c|c|}
\hline \multicolumn{3}{|c|}{ 1. Contributory system (UI) } \\
\hline $\begin{array}{l}\text { Period of contribution } \\
\text { in months }\end{array}$ & $\begin{array}{l}\text { Duration of benefits } \\
\text { in months }\end{array}$ & $\begin{array}{l}\text { Amount of benefits as a percentage of the } \\
\text { Social Security base contribution }\end{array}$ \\
\hline $1-11$ & 0 & $70 \%$ (first 6 months of benefits) \\
\hline $12-17$ & 4 & $60 \%$ (remaining period of benefits) \\
\hline $18-23$ & 6 & \\
\hline $24-29$ & 8 & \\
\hline $30-35$ & 10 & \\
\hline $36-41$ & 12 & \\
\hline $42-47$ & 14 & \\
\hline $48-53$ & 16 & \\
\hline $54-59$ & 18 & \\
\hline $60-65$ & 20 & \\
\hline 66-71 & 22 & \\
\hline$>=72$ & 24 & \\
\hline
\end{tabular}

2. Assistance system (UA) for workers non eligibility for UI Period of contribution in months

Duration of benefits in months With family burdens Without family burdens 
Table 2. Main descriptive statistics

\begin{tabular}{|c|c|c|c|c|c|c|}
\hline \multirow[b]{2}{*}{ Variable } & \multicolumn{3}{|c|}{ UI benefit recipients } & \multicolumn{3}{|c|}{ UA benefit recipients } \\
\hline & $\begin{array}{c}\text { Recall } \\
\operatorname{Mean}(S . D .)\end{array}$ & $\begin{array}{c}\text { New Job } \\
\text { Mean (S.D.) }\end{array}$ & $\begin{array}{c}\text { Censored } \\
\text { Mean (S.D.) }\end{array}$ & $\begin{array}{c}\text { Recall } \\
\operatorname{Mean}(S . D .)\end{array}$ & $\begin{array}{c}\text { New Job } \\
\text { Mean (S.D.) }\end{array}$ & $\begin{array}{c}\text { Censored } \\
\text { Mean (S.D.) }\end{array}$ \\
\hline Males & 0.466 & 0.580 & 0.451 & 0.316 & 0.484 & 0.324 \\
\hline $\begin{array}{l}\text { Worked in a temporary help agency } \\
\text { in previous job }\end{array}$ & 0.020 & 0.021 & 0.007 & 0.016 & 0.039 & - \\
\hline $\begin{array}{l}\text { Qualification level: } \\
\qquad \begin{array}{r}\text { High } \\
\text { Upper-intermediate } \\
\text { Lower-intermediate } \\
\text { Low }\end{array}\end{array}$ & $\begin{array}{l}0.099 \\
0.110 \\
0.260 \\
0.531\end{array}$ & $\begin{array}{l}0.087 \\
0.152 \\
0.360 \\
0.401\end{array}$ & $\begin{array}{l}0.088 \\
0.162 \\
0.391 \\
0.359 \\
\end{array}$ & $\begin{array}{l}0.024 \\
0.093 \\
0.242 \\
0.641\end{array}$ & $\begin{array}{l}0.035 \\
0.099 \\
0.320 \\
0.545\end{array}$ & $\begin{array}{l}0.013 \\
0.052 \\
0.208 \\
0.727\end{array}$ \\
\hline $\begin{array}{l}\text { Mean age at unemployment } \\
\text { spell(years) }\end{array}$ & $\begin{array}{l}33.232 \\
(8.360)\end{array}$ & $\begin{array}{l}31.481 \\
(8.097)\end{array}$ & $\begin{array}{l}32.789 \\
(7.643)\end{array}$ & $\begin{array}{l}34.718 \\
(8.594)\end{array}$ & $\begin{array}{l}31.303 \\
(8.692)\end{array}$ & $\begin{array}{l}32.182 \\
(8.396)\end{array}$ \\
\hline $\begin{array}{l}\text { Unemployment duration: } \\
\qquad \begin{array}{r}>1 \text { month and }<=4 \text { months } \\
>4 \text { months and }<=1 \text { year } \\
>1 \text { year }\end{array}\end{array}$ & $\begin{array}{c}4.556 \\
(3.385) \\
0.567 \\
0.375 \\
0.058\end{array}$ & $\begin{array}{c}6.108 \\
(4.483) \\
0.427 \\
0.438 \\
0.134\end{array}$ & $\begin{array}{l}- \\
-\end{array}$ & $\begin{array}{c}5.424 \\
(3.374) \\
0.423 \\
0.519 \\
0.058\end{array}$ & $\begin{array}{c}6.283 \\
(4.559) \\
0.399 \\
0.460 \\
0.140\end{array}$ & $\begin{array}{l}- \\
-\end{array}$ \\
\hline Type of contract in previous job: & & & & & & \\
\hline $\begin{array}{r}\text { Permanent } \\
\text { Discontinuous open ended contracts } \\
\text { Temporary } \\
\text { Other contract type }\end{array}$ & $\begin{array}{l}0.050 \\
0.086 \\
0.801 \\
0.062\end{array}$ & $\begin{array}{l}0.216 \\
0.010 \\
0.726 \\
0.048\end{array}$ & $\begin{array}{c}0.394 \\
- \\
0.570 \\
0.035\end{array}$ & $\begin{array}{l}- \\
0.136 \\
0.715 \\
0.148\end{array}$ & $\begin{array}{l}0.018 \\
0.031 \\
0.921 \\
0.031\end{array}$ & $\begin{array}{c}- \\
- \\
0.987 \\
0.013\end{array}$ \\
\hline Number of previous jobs & $\begin{array}{c}1.935 \\
(1.464)\end{array}$ & $\begin{array}{c}1.690 \\
(1.064)\end{array}$ & $\begin{array}{c}1.468 \\
(0.715)\end{array}$ & $\begin{array}{c}1.957 \\
(1.441)\end{array}$ & $\begin{array}{c}1.977 \\
(1.345)\end{array}$ & $\begin{array}{c}1.623 \\
(0.795)\end{array}$ \\
\hline Number of children: & & & & & & \\
\hline $\begin{array}{r} \\
1 \\
1 \\
2 \\
>=3\end{array}$ & $\begin{array}{l}0.600 \\
0.194 \\
0.162 \\
0.043\end{array}$ & $\begin{array}{l}0.697 \\
0.151 \\
0.123 \\
0.029\end{array}$ & $\begin{array}{l}0.511 \\
0.243 \\
0.187 \\
0.060\end{array}$ & $\begin{array}{l}0.495 \\
0.196 \\
0.223 \\
0.085\end{array}$ & $\begin{array}{l}0.637 \\
0.145 \\
0.154 \\
0.062\end{array}$ & $\begin{array}{l}0.364 \\
0.208 \\
0.298 \\
0.129\end{array}$ \\
\hline Firm size (number of employees): & & & & & & \\
\hline $\begin{array}{r}<<=10 \\
>10 \&<=50 \\
>50 \&<=200 \\
>200 \&<=1000 \\
>1000\end{array}$ & $\begin{array}{l}0.243 \\
0.271 \\
0.233 \\
0.150 \\
0.104\end{array}$ & $\begin{array}{l}0.363 \\
0.315 \\
0.171 \\
0.113 \\
0.039\end{array}$ & $\begin{array}{l}0.440 \\
0.271 \\
0.162 \\
0.109 \\
0.018\end{array}$ & $\begin{array}{l}0.215 \\
0.274 \\
0.261 \\
0.175 \\
0.074\end{array}$ & $\begin{array}{l}0.355 \\
0.308 \\
0.219 \\
0.089 \\
0.027\end{array}$ & $\begin{array}{l}0.428 \\
0.259 \\
0.208 \\
0.091 \\
0.013\end{array}$ \\
\hline Entitlement period: & & & & & & \\
\hline $\begin{array}{r}3 \text { months } \\
4 \text { months } \\
5 \text { months } \\
6 \text { months } \\
8 \text { months } \\
10 \text { months } \\
12 \text { months } \\
14 \text { months } \\
16 \text { months } \\
18 \text { months } \\
20 \text { months } \\
21 \text { months } \\
22 \text { months } \\
24 \text { months }\end{array}$ & $\begin{array}{c}- \\
0.425 \\
- \\
0.213 \\
0.103 \\
0.071 \\
0.064 \\
0.035 \\
0.017 \\
0.016 \\
0.019 \\
- \\
0.017 \\
0.021\end{array}$ & $\begin{array}{c}- \\
0.327 \\
- \\
0.171 \\
0.124 \\
0.068 \\
0.064 \\
0.037 \\
0.035 \\
0.022 \\
0.021 \\
- \\
0.025 \\
0.105\end{array}$ & $\begin{array}{c}- \\
0.271 \\
- \\
0.095 \\
0.053 \\
0.042 \\
0.070 \\
0.046 \\
0.035 \\
0.049 \\
0.035 \\
- \\
0.056 \\
0.247\end{array}$ & $\begin{array}{c}0.049 \\
0.058 \\
0.039 \\
0.832 \\
- \\
- \\
- \\
- \\
- \\
- \\
- \\
0.021 \\
- \\
-\end{array}$ & $\begin{array}{c}0.027 \\
0.021 \\
0.018 \\
0.899 \\
- \\
- \\
- \\
- \\
- \\
- \\
- \\
0.034 \\
- \\
-\end{array}$ & $\begin{array}{c}0.013 \\
0.013 \\
- \\
0.922 \\
- \\
- \\
- \\
- \\
- \\
- \\
- \\
0.052 \\
- \\
-\end{array}$ \\
\hline $\begin{array}{l}\text { Average entitlement period } \\
\text { (months) }\end{array}$ & $\begin{array}{c}7.568 \\
(4.906)\end{array}$ & $\begin{array}{c}9.750 \\
(6.688)\end{array}$ & $\begin{array}{l}13.296 \\
(8.139)\end{array}$ & $\begin{array}{c}6.018 \\
(2.346)\end{array}$ & $\begin{array}{c}6.368 \\
(2.805)\end{array}$ & $\begin{array}{c}6.714 \\
(0.339)\end{array}$ \\
\hline Sample size & 1,274 & 3,275 & 284 & 376 & 706 & 77 \\
\hline
\end{tabular}

Notes: Standard deviations in parentheses 
Table 3. Estimates from the discrete time duration model by type of benefit received.

\begin{tabular}{|c|c|c|c|c|c|c|c|c|c|c|c|c|}
\hline & \multicolumn{6}{|c|}{ UI recipients } & \multicolumn{6}{|c|}{ UA recipients } \\
\hline & \multicolumn{3}{|c|}{ New job } & \multicolumn{3}{|c|}{ Recall } & \multicolumn{3}{|c|}{ New job } & \multicolumn{3}{|c|}{ Recall } \\
\hline & Coef. & S.E. & Sign. & Coef. & S.E. & Sign. & Coef. & S.E. & Sign. & Coef. & S.E. & Sign. \\
\hline Gender $($ male $=1)$ & 0.369 & 0.052 & $* * *$ & -0.124 & 0.071 & $*$ & 0.492 & 0.122 & $* * *$ & -0.148 & 0.145 & \\
\hline Age (at unemploy.spell) & 0.011 & 0.021 & & -0.100 & 0.024 & $* * *$ & -0.006 & 0.037 & & 0.007 & 0.048 & \\
\hline $\mathrm{Age}^{2}$ & 0.001 & 0.001 & & 0.002 & 0.001 & $* * *$ & 0.001 & 0.001 & & 0.001 & 0.001 & \\
\hline \multicolumn{13}{|l|}{ Qualification level: } \\
\hline High & 0.176 & 0.092 & $*$ & 0.460 & 0.139 & $* * *$ & 0.480 & 0.304 & & 0.468 & 0.421 & \\
\hline Med.-High & - & - & - & - & - & - & - & - & - & - & - & - \\
\hline Medium-Low & 0.068 & 0.066 & & -0.050 & 0.109 & & 0.094 & 0.161 & & 0.111 & 0.224 & \\
\hline Low & -0.105 & 0.067 & & 0.144 & 0.103 & & -0.195 & 0.158 & & -0.020 & 0.213 & \\
\hline \multicolumn{13}{|l|}{ Type of contract: } \\
\hline $\begin{array}{l}\text { Permanent contract } \\
\text { Discontinuous open } \\
\text { ended contracts }\end{array}$ & 0.032 & $\begin{array}{c}- \\
0.210\end{array}$ & - & 2.660 & $\begin{array}{c}- \\
0.193\end{array}$ & $* * *$ & $\begin{array}{c}- \\
-0.149\end{array}$ & $\begin{array}{c}- \\
0.451\end{array}$ & - & 2.154 & $\begin{array}{c}- \\
0.747\end{array}$ & $\begin{array}{l}- \\
* * *\end{array}$ \\
\hline Temporary & 0.157 & 0.062 & $* *$ & 1.187 & 0.135 & $* * *$ & 0.064 & 0.356 & & 0.943 & 0.702 & \\
\hline Other type & 0.339 & 0.114 & $* * *$ & 1.195 & 0.186 & $* * *$ & -0.315 & 0.436 & & 2.016 & 0.742 & $* * *$ \\
\hline \multicolumn{13}{|l|}{ Firm size (employees): } \\
\hline$<=10$ & - & - & - & - & - & - & - & - & - & - & - & - \\
\hline$>10 \&<=50$ & 0.142 & 0.056 & $* *$ & 0.154 & 0.088 & $*$ & 0.090 & 0.108 & & 0.181 & 0.162 & \\
\hline$>50$ and $<=200$ & 0.197 & 0.070 & $* * *$ & 0.502 & 0.095 & $* * *$ & -0.021 & 0.121 & & 0.377 & 0.168 & $* *$ \\
\hline$>200$ and $<=1000$ & 0.138 & 0.079 & $*$ & 0.579 & 0.109 & $* * *$ & -0.005 & 0.178 & & 1.071 & 0.203 & $* * *$ \\
\hline$>1000$ & -0.064 & 0.119 & & 1.050 & 0.132 & $* * *$ & -0.369 & 0.274 & & 0.807 & 0.275 & $* * *$ \\
\hline Worked in a THA & 0.102 & 0.154 & & -0.021 & 0.225 & & 0.683 & 0.250 & $* * *$ & -0.163 & 0.450 & \\
\hline \multicolumn{13}{|l|}{ Months until exhaustion } \\
\hline $\mathrm{UB}>18$ & - & - & - & - & - & - & - & - & - & - & - & - \\
\hline UB 12 to 18 & 0.145 & 0.101 & & 0.289 & 0.197 & & 0.674 & 0.600 & & -1.866 & 0.769 & $* *$ \\
\hline UB 5 to 11 & 0.198 & 0.093 & $* *$ & 0.461 & 0.173 & $* * *$ & 0.003 & 0.536 & & -0.180 & 0.587 & \\
\hline UB 2 to 4 & 0.259 & 0.096 & $* * *$ & 0.509 & 0.173 & $* * *$ & 0.402 & 0.523 & & -0.342 & 0.538 & \\
\hline UB1 & 0.334 & 0.120 & $* * *$ & 0.392 & 0.205 & $*$ & -0.148 & 0.631 & & -1.145 & 0.644 & $*$ \\
\hline UB0 & 0.628 & 0.128 & $* * *$ & 1.212 & 0.219 & $* * *$ & 0.250 & 0.636 & & -1.346 & 0.659 & $* *$ \\
\hline UB-1 & 0.882 & 0.138 & $* * *$ & 1.345 & 0.233 & $* * *$ & 0.340 & 0.661 & & -2.126 & 0.703 & $* * *$ \\
\hline UB -2 to -4 & 0.737 & 0.138 & $* * *$ & 1.537 & 0.230 & $* * *$ & 0.610 & 0.649 & & -1.451 & 0.664 & $* *$ \\
\hline $\mathrm{UB}-5$ to -10 & 0.720 & 0.169 & $* * *$ & 0.789 & 0.284 & *** & 0.730 & 0.757 & & -0.394 & 0.754 & \\
\hline $\mathrm{UB}>-10$ & 0.727 & 0.241 & $* * *$ & 1.003 & 0.499 & $* *$ & 1.962 & 1.063 & $*$ & -2.178 & 1.279 & $*$ \\
\hline Number of previous jobs & 0.062 & 0.021 & $* * *$ & 0.113 & 0.025 & $* * *$ & 0.109 & 0.043 & $* * *$ & 0.107 & 0.047 & $* *$ \\
\hline \multicolumn{13}{|l|}{ Number of children: } \\
\hline 0 & - & - & - & - & - & - & -8 & - & - & - & - & - \\
\hline 1 & -0.282 & 0.063 & $* * *$ & 0.091 & 0.088 & & -0.341 & 0.132 & $* * *$ & 0.226 & 0.160 & \\
\hline 2 & -0.197 & 0.070 & $* * *$ & 0.139 & 0.098 & & -0.322 & 0.134 & $* *$ & -0.032 & 0.163 & \\
\hline$>=3$ & -0.553 & 0.132 & $* * *$ & -0.094 & 0.169 & & -0.265 & 0.189 & & -0.053 & 0.225 & \\
\hline \multicolumn{13}{|l|}{ Sector of activity: } \\
\hline Manufacturing & - & - & - & - & - & - & - & - & - & - & - & - \\
\hline Agriculture & 0.523 & 0.429 & & 0.746 & 0.454 & & 0.370 & 0.462 & & 0.209 & 0.763 & \\
\hline Construction & 0.093 & 0.074 & & -0.137 & 0.111 & & 0.053 & 0.170 & & -0.522 & 0.245 & $* *$ \\
\hline Services & 0.103 & 0.058 & $*$ & -0.184 & 0.083 & $* *$ & 0.053 & 0.131 & & -0.223 & 0.160 & \\
\hline Regional unempl.rate (tvc) & 0.008 & 0.016 & & -0.112 & 0.025 & $* * *$ & -0.013 & 0.030 & & 0.016 & 0.044 & \\
\hline
\end{tabular}

\begin{tabular}{l|c|c}
\multicolumn{2}{c}{ Mass points and probability: } & -0.013 \\
\hline$\varepsilon_{1}$ (s.e.) & $-4.339(0.934)^{* * *}$ & $-3.467(0.915)^{* * *}$ \\
$\varepsilon_{2}$ (s.e.) & $-2.874(0.382)^{* * *}$ & $-2.865(1.368)^{* *}$ \\
$\operatorname{Pr}\left(\varepsilon_{1}\right)$ & 0.081 & 0.558 \\
$\operatorname{Pr}\left(\varepsilon_{2}\right)$ & 0.919 & 0.442 \\
\hline Number of observations & 28,913 & 7,369 \\
\hline Number of individuals & 4,833 & 1,159 \\
\hline Log-likelihood & -14523.241 & -3556.757
\end{tabular}

Note: See Table A.3 
Figure 1A. Kaplan-Meier hazard rates from unemployment into recall or a different employer. UI recipients

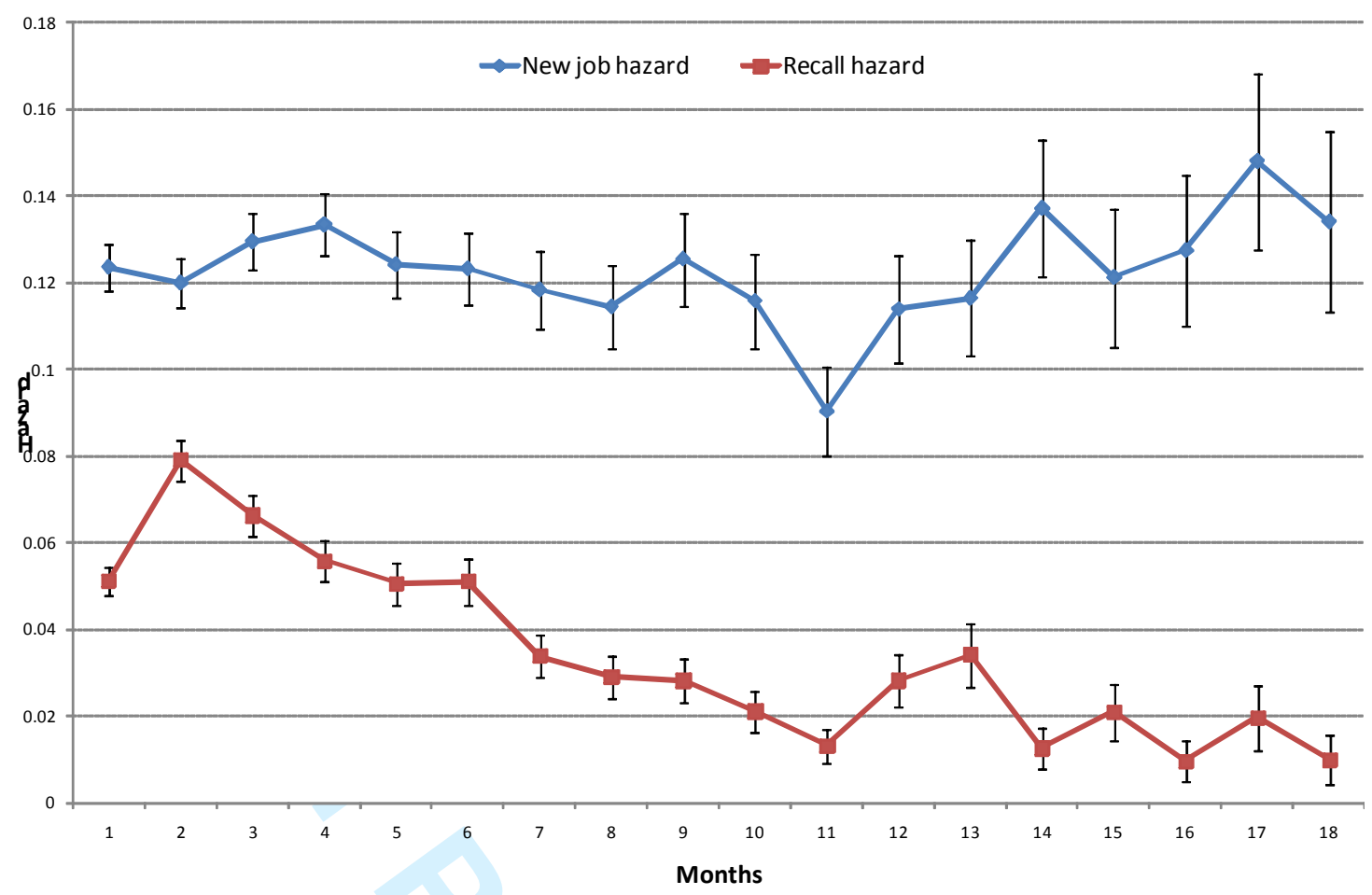

Figure 1B. Kaplan-Meier hazard rates from unemployment into recall or a different employer. UA recipients

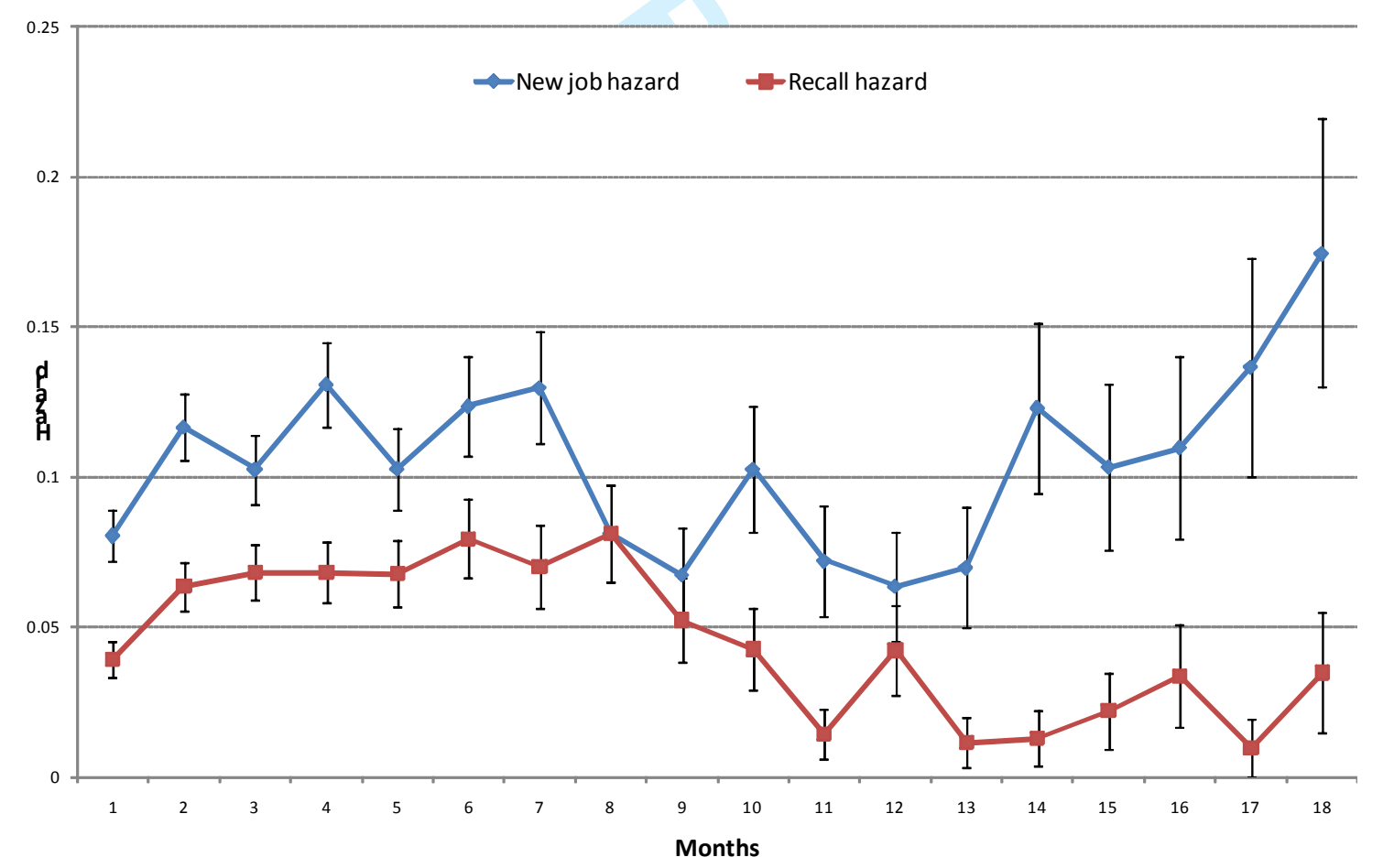


Figure 2A. Benefit expiry effect on exit rates. Recall vs. New jobs. UI recipients

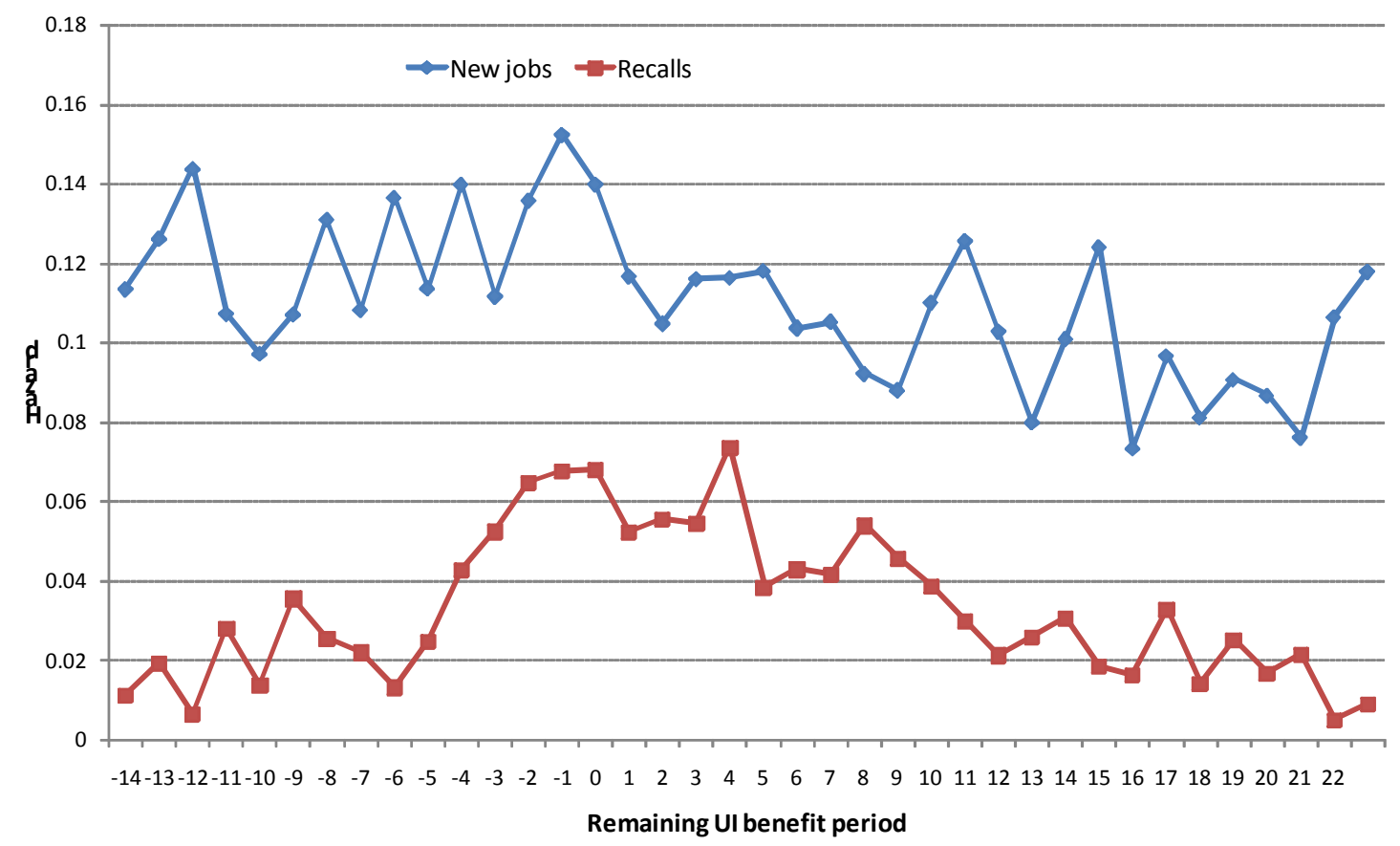

Figure 2B. Benefit expiry effect on exit rates. Recall vs. New jobs. UA recipients

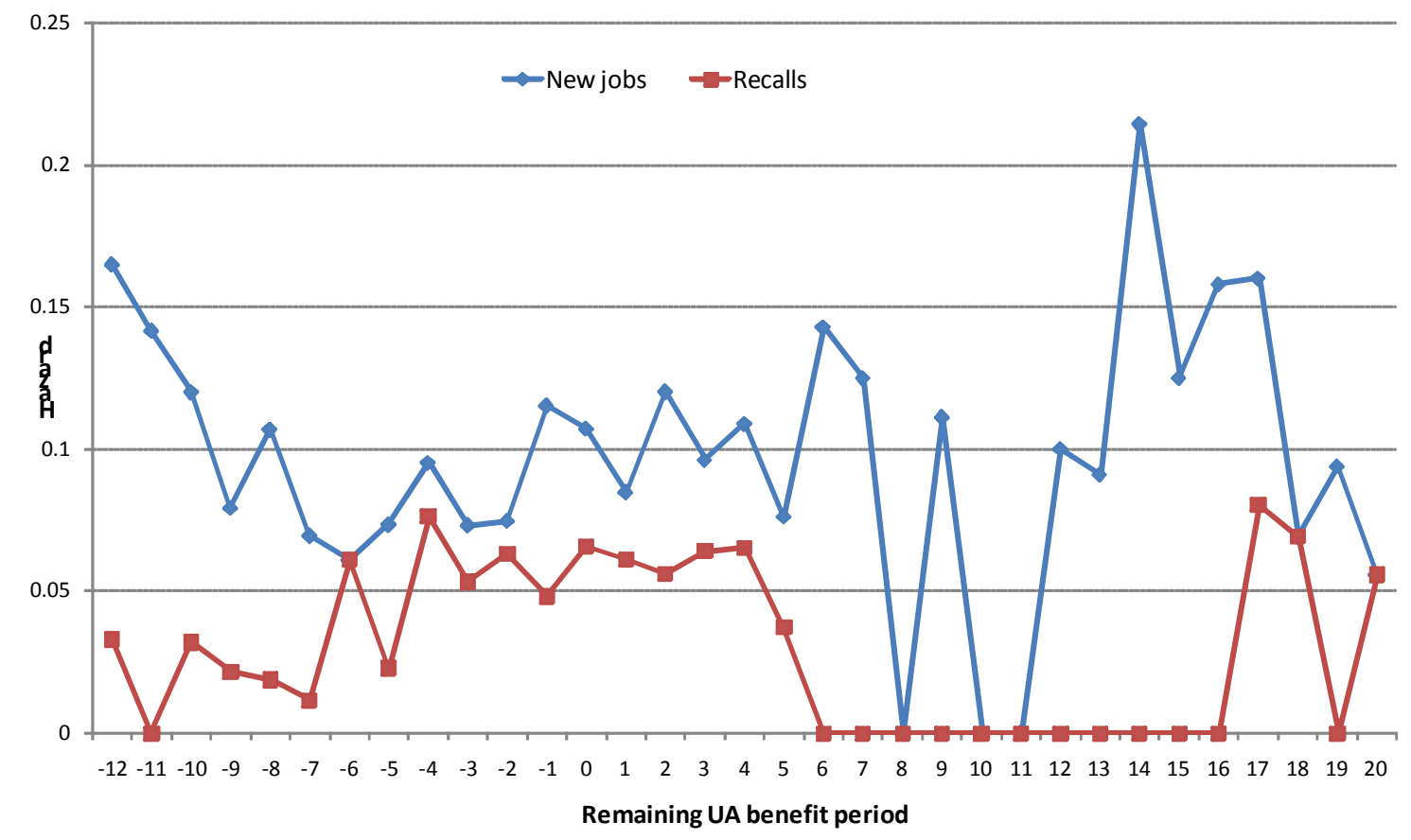


Figure 3A. Estimated hazard rates from unemployment into recall or a different employer, after controlling for observed and unobserved heterogeneity. Predicted values are obtained at the means of covariates. UI recipients

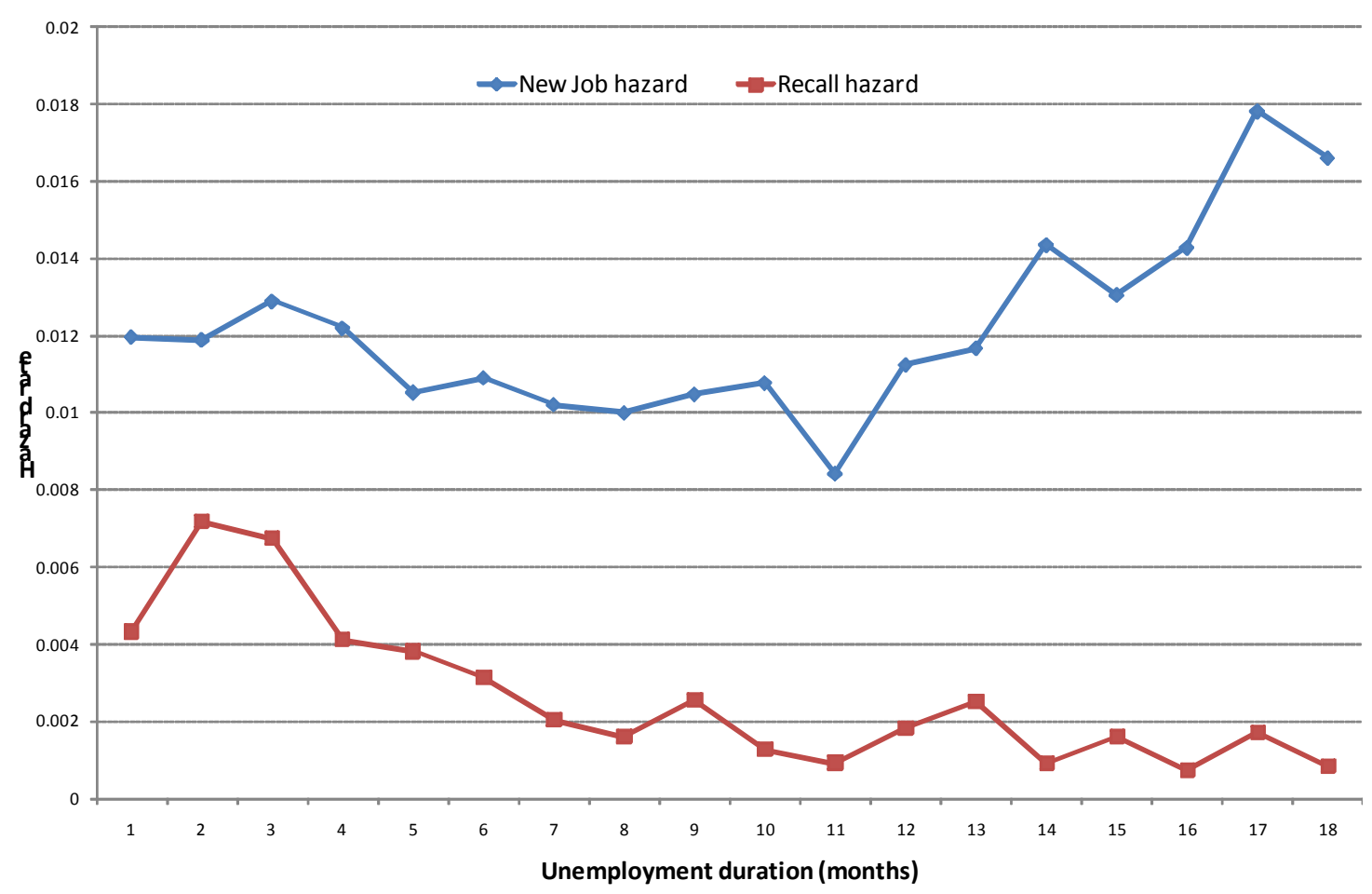

Figure 3B. Estimated hazard rates from unemployment into recall or a different employer, after controlling for observed and unobserved heterogeneity. Predicted values are obtained at the means of covariates. UA recipients

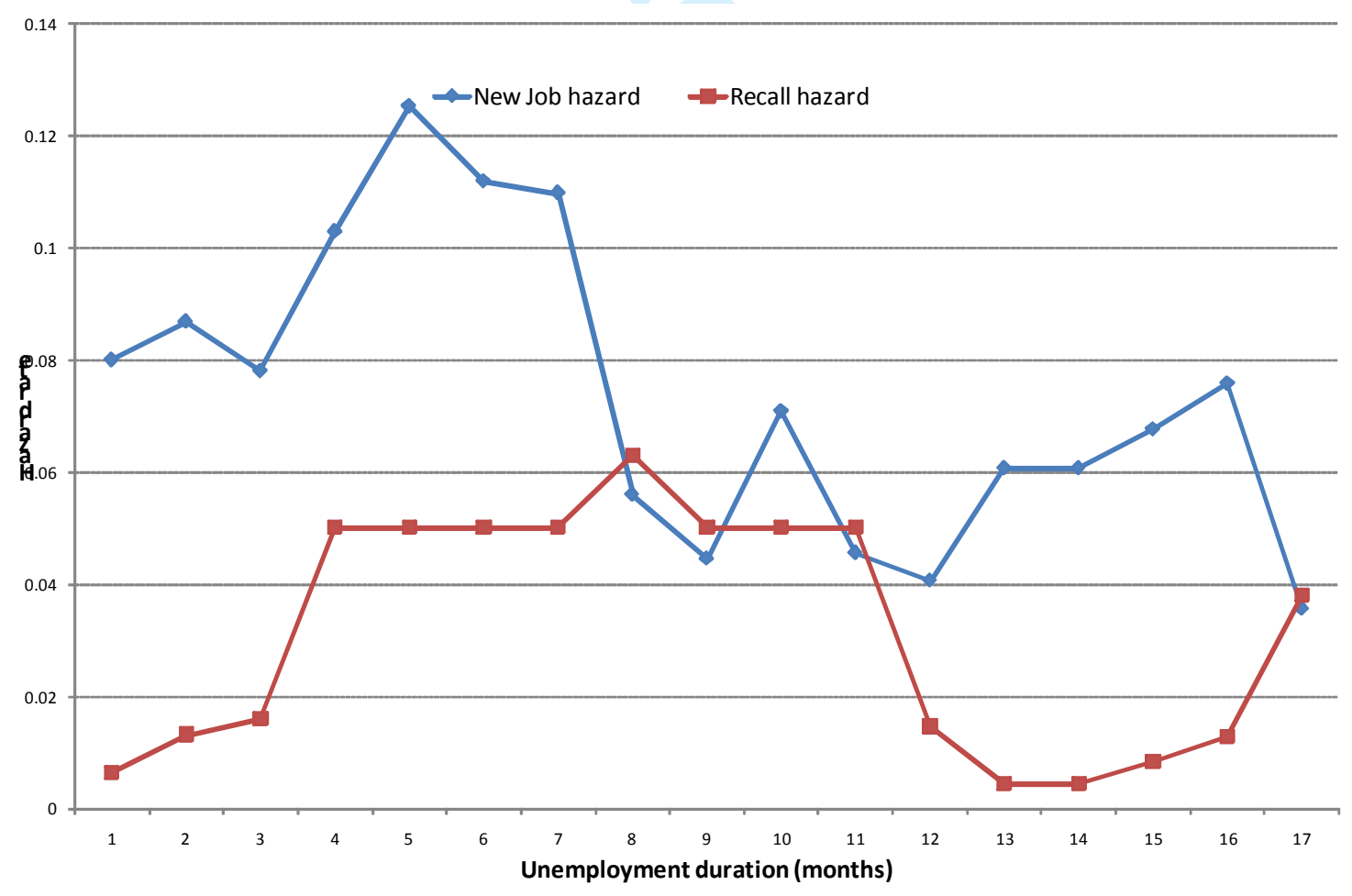

